
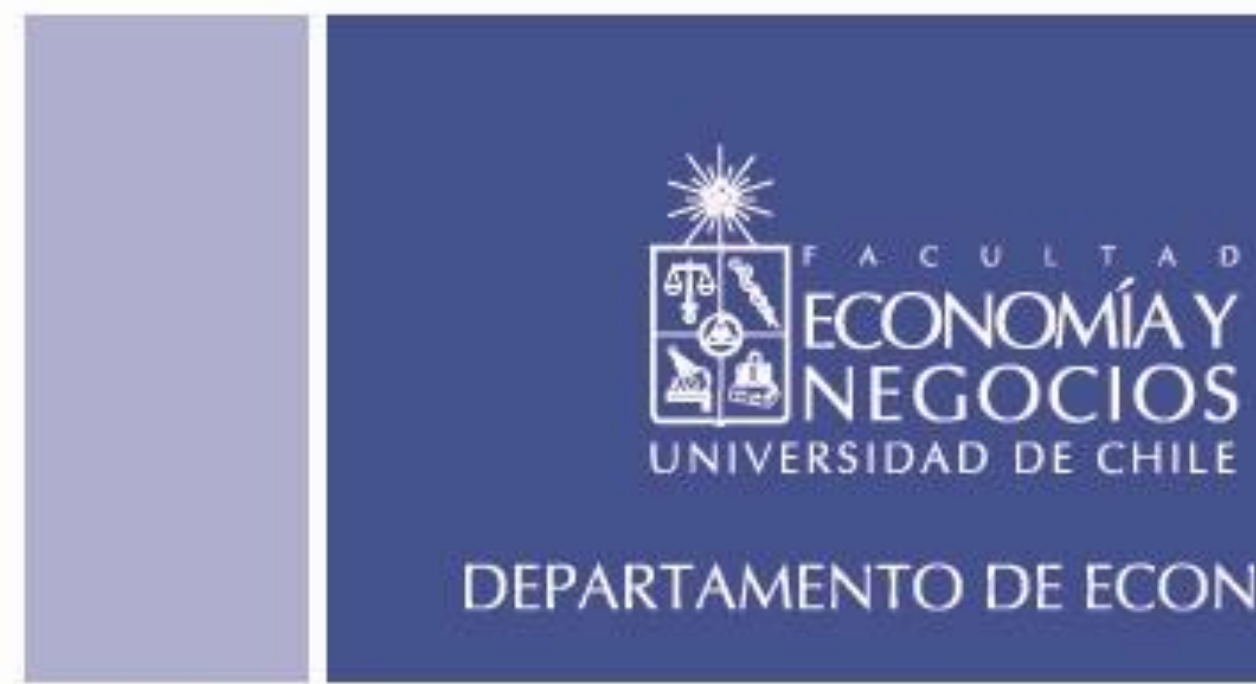

DEPARTAMENTO DE ECONOMÍA

\title{
COMMODITY PRICES, MONETARY POLICY AND INFLATION
}

\section{SDT 359}

Autor: José De Gregorio

Santiago, Julio de 2012

La serie de Documentos de Trabajo (SDT) del Departamento de Economía de la Universidad de Chile en versión PDF puede descargarse en la dirección electrónica www.econ.uchile.cl/SDT . Para contactar al editor ejecutivo de SDT remitirse a sdt@econ.uchile.cl 


\title{
Commodity Prices, Monetary Policy ANd Inflation*
}

\author{
José De Gregorio \\ Universidad de Chile \\ July 2012
}

\begin{abstract}
During the second half of the 2000s, the world experienced a rapid and substantial rise in commodity prices. This shock posed complex challenges for monetary policy, in particular due to the significant increase in food and energy prices, and the repercussions they had on aggregate inflation measures. This paper discusses the role of commodity price shocks in monetary policy in the light of recent episodes of such shocks. It begins by discussing whether monetary policy should target core or headline inflation, and what should be the role of commodity price shocks in setting interest rates. It is argued that there are good reasons to focus on headline inflation, as most central banks actually do. Although core inflation provides a good indicator of underlying inflationary pressures, the evolution of commodity prices should not be overlooked, because of pervasive second-round effects. This paper reviews the evidence on the rise of inflation across countries and reports that food inflation, more than energy inflation, has relevant propagation effects on core inflation. This finding is particularly important in emerging market economies, where the share of food in the consumer basket is significant. The evidence also shows that countries that had lower inflation during the run up of commodity prices before the global crisis had more inflation in the subsequent rise after the global crisis, suggesting that part of the pre-crisis inflationary success may have been due to repressed inflation. This paper also discusses other factors that may explain different inflationary performances across countries.

JEL No. E31, E5, E61
\end{abstract}

\footnotetext{
* Prepared for the Conference on Policy Responses to Commodity Price Movements, organized by the IMF and the Central Bank of Turkey, April 2012. Part of this paper was written while I was a visiting scholar at the Research department of the IMF, and I am very grateful for its hospitality. I am also very grateful for discussions with and suggestions from Larry Ball, Pierre Olivier Gourinchas, Thomas Helbling and Ayhan Kose, and conference participants, as well as for the valuable comments and assistance from Felipe Labbé.
} 


\section{Introduction}

The inflationary consequences of rising commodity prices have represented a key challenge for monetary policy. Rising commodity prices result in rising inflation, but at the same time it can have different implications on output and income depending on whether the country is an exporter or importer of commodities. For the purposes of this paper I will consider an economy that is a net importer of commodities, and local demand for the commodity is significant. This commodity may be an intermediate input, such as oil, or a final good, such as gasoline or food. Therefore, a commodity price shock is an inflation shock and has negative effects on income at the same time. I will not focus on natural resource abundant economies, where the rise in commodity prices represents mainly a positive wealth effect, in particular when the fraction of the production of the commodity consumed at home is small. ${ }^{1}$

Considering countries that are abundant in natural resources that are not consumed domestically would add additional channels, which can be treated separately. For example, a commodity price shock generates mostly a wealth effect, with effects on the exchange rate and aggregate demand. The issue becomes how to manage monetary and fiscal policy to smooth the commodity price shock. ${ }^{2}$ In this paper I focus on managing monetary policy when confronting commodity price inflation shocks.

Let us consider, for example, the case of oil. Inflation rises through the direct effects on gasoline prices and indirectly through a rise in costs. In addition, an oil price shock is analogous to a negative productivity shock. Therefore inflation rises and output slows down. Although in principle one could think that the implications for monetary policy are ambiguous, they are not. Some degree of accommodation may be needed, and this depends on the output effects, and on the size and duration of the shock, but the direction of monetary policy is to reduce the monetary impulse. ${ }^{3}$

The inflationary effect of an oil price shock calls for a tightening of monetary policy. The effects on activity also calls for tightening, since the effects on output are mostly a fall in full-employment output, since the energy shock is equivalent to a negative productivity shock, and hence the output gap increases, ${ }^{4}$ inducing further inflationary pressures. At first sight, this prescription may look somewhat counterintuitive. Indeed, a negative output shock

\footnotetext{
${ }^{1}$ This is, for example, the case of soy beans in Argentina, copper in Chile or oil in Nigeria.

${ }^{2}$ For details on managing the copper price boom in Chile, see De Gregorio and Labbé (2011).

${ }^{3}$ See, for example, Medina and Soto (2005) and Batini and Terenau (2010).

${ }^{4}$ The output gap is the difference between current output and full-employment output, so an increase in the gap means an increase in economic activity.
} 
should reduce inflationary pressures. However, an oil price shock represents a shock to full employment output, reducing the output gap and generating inflation beyond its direct effects.

However, there are some caveats to this conclusion. As I discuss later on, there are mitigating demand effects, which could be very important in the case of a food price shock, since the commodity price boom may result in a decline in the terms of trade and national income. In addition, a credible inflation targeting regime may need a much smaller response when facing transitory supply shocks, and indeed as I document in this paper, the fact that the recent oil shocks have had small effects on inflation and activity hinges to a large extent on the conduct of monetary policy geared toward price stability.

The recent experience with commodity price shocks has been very significant. In the mid2000s all commodity prices started rising sharply (figure 1). The initial reaction in policy and academic circles was how to react to a transitory commodity price shock. In this case, there were good reasons to think that a short-lived price shock should not require decisive policy reaction. However, the reality turned out to be quite different. Commodity prices kept rising to unprecedented levels and the change was much more persistent. Only at the peak of the subprime crisis, late 2008, commodity prices suffered a major reversal, but even in a world that had not fully recovered from the crisis, commodity prices rose again.

The magnitude and persistence of high commodity prices were not expected some years ago, and hence, it is not appropriate to conduct monetary policy under the assumption that the shock is temporary. Today it is better to work with the assumption that there has been a persistent change in the relative price of commodities. Economies must adjust to these new relative prices, but during the adjustment monetary policy must prevent increases in inflation that may end up being too costly to revert. Excessive propagation feeds back into prices through indexation and rising inflationary expectations.

A key issue on the impact of a commodity price boom is on its sources. Historically, many shocks, in particular oil price shocks, have been related to supply disruptions. Hence, they have tended to produce high inflation and falling output. This time, however, its source has been rising world demand for commodities, especially from emerging markets. Indeed, the rise in commodity prices can be interpreted as an increase in the world relative prices of food and energy, which have been particularly strong in countries with a high share of consumption in food and energy. This is consistent with the overall view that the commodity price boom came with an increase in world inflation and without serious recessionary effects, despite those stemming from the global financial crisis. An additional factor that has ameliorated the negative output effects of rising commodity prices has been the fact that most emerging markets are exporters of some commodity, and hence, this has resulted in an improvement in emerging markets' terms of trade. This has clearly been the case in most Latin American countries. 
These two commodity price booms have resulted in higher inflation, and the purpose of this paper is to analyze some relevant issues from the standpoint of monetary policy. For analytical purposes, I will define two commodity price booms, one ranging from the third quarter of 2006 to the third quarter of 2008, and the other from the third quarter of 2009 to the third quarter of 2011. The reason to define both time spans this way was to have equally sized episodes (nine quarters), which should facilitate comparisons.

Commodity price shocks result in an increase in food and energy inflation. They are mechanically passed on to headline inflation. The magnitude of these effects depends on the weight of each component in the CPI. But in addition, there are the so-called second round effects, which refer to the indirect impact on other prices, through cost-push or demand-pull pressures. Figures 2 and 3 show the correlation between food and energy inflation with headline and core inflation for a sample of 34 countries in both episodes. ${ }^{5}$ It is interesting to note that in most countries there was a significant increase in food and energy inflation, varying across countries and episodes. The simple correlation shows that the rise in food and energy prices had effects on headline inflation.

The increase in food prices also had important second-round effects, which, as the figures show, are already affecting core inflation two quarters into the shock. The second-round effects of energy are weaker, in particular during the second episode. This is consistent with the evidence-discussed later-on the relevance of food vis-à-vis energy in the propagation of inflation.

The paper follows in two main sections. Section 2 is devoted to an analytical discussion on commodity prices and monetary policy. In the first part I take on the issue of whether the inflation target should be set in terms of core or headline inflation, and regardless of the target, how monetary policy must react to rising commodity-price inflation. Despite the fact that core inflation is a better measure of underlying inflationary pressures, setting up the target in terms of headline inflation is desirable and it is the usual practice of central banks. In addition, ignoring the developments of headline inflation may lead to underestimate future inflation when hit by long-lasting commodity price shocks. Then, I present a simplified model to discuss the channels through which commodity prices affect the economy and their implications for monetary policy. I distinguish the direct impact on inflation, and the impacts on full-employment output and aggregate demand.

In section 3 of the paper I look at the empirical evidence of the two episodes of commodity price booms. It reviews the literature on second-round effects and propagation, and present

\footnotetext{
${ }^{5}$ The sample is based on data availability at the MEI-OECD database. The advantage of this data is that classification is the same across countries, but it only includes OECD countries. The data is available at http://stats.oecd.org/index.aspx?DatasetCode=MEI PRICES.
} 
new evidence on the relevance of food and energy in the propagation of inflation. The evidence shows that energy has very limited second-round effects, while those of food are much more important. The paper concludes in section 4 with some final remarks.

\section{Commodity prices and monetary policy}

In this section I will discuss the role that commodity price shocks (CPS) play on monetary policy. I will look at this issue in the context of an inflation-targeting central bank, that makes the price stability goal explicit by communicating a numerical inflation target. However, the points raised here could also be applied to all central banks with a clear mandate of price stability.

In this framework I will assume that the central bank has an inflation target, defined over some range of tolerance and a policy horizon. The policy horizon is the time period within which the central bank plans to correct deviations from the target. Since the central bank has to conduct monetary policy to achieve the target in the future, in order to fulfill the target on average over time, a key variable is the forecast that the central bank makes about the future path of inflation. Indeed, the central bank should pursue a policy that ensures that forecast inflation reaches the target in the policy horizon. Then, in practice the central bank has as an intermediate target its forecast inflation at the policy horizon.

Before proceeding with a review of the literature and policy discussion I will discuss a couple of analytical points regarding policy evaluation exercises. Most of they are done in the context of dynamic stochastic general equilibrium (DSGE) models, and the structure is a sticky price model along the lines of the new-Keynesian models of policy evaluation (Galí and Gertler, 2007). In order to perform the policy evaluation, these models maximize welfare, which is typically the utility of the representative consumer. Then, the maximization of the welfare function can be converted, to a second-order approximation, to the traditional minimization of a quadratic loss function that depends on deviations of inflation $(\pi)$ from its target $(\bar{\pi})$, and deviations of output from the full-employment output level (output gap, y $\bar{y}) .{ }^{6}$ The specific inflation rate that enters the loss function should be the index to target. However, if the quadratic loss function is assumed rather than derived from the consumers' utility function, the index to target becomes an assumption rather than an implication of the model. But even when the loss function is derived from a welfare function, the approximation is very specific to the model's assumptions, and evaluating different and more general environments is what the recent analytical work has done.

Another, different, issue is how to conduct monetary policy in order to achieve the target, regardless of whether this is based on core or headline inflation. In general, the instrument to

\footnotetext{
${ }^{6}$ For a derivation of this approximation, see Woodford (2003) and Galí (2008).
} 
conduct monetary policy is the interest rate, and hence the question would be: how must interest rates react to commodity price shocks? Indeed this question has led to heated debate on whether a central bank that targets headline inflation should pay more attention to developments in headline or core inflation. ${ }^{7}$

As a first approximation we can think that the central bank determines the interest rate according to some feedback rule, by which a given state of the economy implies a certain monetary policy stance. This rule should be consistent with the target. The Taylor rule is the most widely known among feedback rules, and adjusts the interest rate to the output gap and inflation deviations from the target. More elaborated rules also include other observed variables as well as the inflation forecast some periods ahead. For example, a central bank with a horizon of two years may use inflation one year or 18 months ahead in the policy rule. Inflation forecast two years ahead should be equal to the target, so it should not enter the rule.

Most standard models for policy evaluation consider different feedback policy rules, and then evaluate their relative performance in terms of welfare. In the context of this paper, the purpose would be to compare rules that use core inflation with rules that use headline inflation. However, this strategy has some limitations. First, the number of potential rules is unlimited, and indeed it is likely that a linear combination of the rules being examined may be superior. And second, central banks do not operate following mechanical rules. Rules, such as the Taylor rule, are a reduced form to interpret the behavior of monetary policy, even to calibrate models in central banks, but do not represent actual decision-making in central banks, nor optimal monetary policy. An optimal rule should be an interest rate path that maximizes welfare, and this can be better approximated with a path for the interest rate that ensures that the inflation forecast at the policy horizon equals the inflation target (Svensson, 1999; Woodford, 2007). In this context, monetary policy should react to all variables and shocks that affect the inflation forecast, which should equal the inflation target at the policy horizon. ${ }^{8}$

In the remainder of this section I will look at the two separate questions of which index should be targeted, and how should monetary policy react to CPS. More concretely, the two questions with a summary of the answers are:

- What price index should a central bank target? Although initially the theory emphasized the use of a core price measure as a target, it seems more reasonable to

\footnotetext{
${ }^{7}$ See, for example, the debate between Paul Krugman and Lorenzo Bin Smaghi reported in Lenza and Reichlin (2011).

${ }^{8}$ This type of models can also be used to define the optimal monetary policy strategy, for example, whether a strict inflation target is preferable, but in this discussion I will focus on flexible inflation target regimes.
} 
use the headline measure, especially in inflation-targeting economies. More recent analytical developments show the advantages of targeting headline inflation.

- $\quad$ Should monetary policy respond to CPS? Regardless of the index used to target inflation, monetary policy should respond to CPS to stabilize prices, but the strength of the response depends on the characteristics of the economy as well as those of the specific shock. Nevertheless, core inflation is one of the best measures to evaluate the underlying inflationary pressures. ${ }^{9}$

\subsection{What price index should central banks target?}

Academic research has learned a lot from actual policymaking in inflation-targeting countries, but has also had a profound impact on how monetary policy is conducted. Indeed, today most inflation-targeting central banks use DSGE models to evaluate policies, produce forecasts and simulate the economy when facing different shocks. However, an area where definite prescriptions have been rather elusive and sometime at odds with the facts is on the relevant price index to define the inflation target. Some recent research is finding more justification for the current conduct of central banks, which usually aims to target headline CPI. Before analyzing the actual conduct of central banks it is useful to start with the lessons taught by the academic literature.

First of all, it is useful to clarify what I mean by core inflation. There are many different measures for core inflation. Measures differ significantly across countries and they tend to be tailored to the reality of each particular case. The simplest one is just to exclude some goods that may have highly volatile prices, such as perishable foods. These goods may be affected by seasonal patterns or sudden and short-lived shocks. Of course, central banks should not pay attention to a spike in a price of one particular food item, which usually is reverted over a short period of time.

However, given developments of recent years, it is more interesting and relevant to focus on the rate of inflation excluding energy and food. Within OECD countries inflation excluding food and energy ranges from 60 percent in the case of Poland, where food weighs 24 percent and energy 16, to 84 in the United States, with food and energy being about 8 percent of the CPI each. ${ }^{10}$ The share of food is even higher in lower-income countries. In countries like Indonesia and the Philippines the share of food is about 40 percent.

\footnotetext{
${ }^{9}$ Indeed, in Spanish the translation of "core inflation” is “inflación subyacente” (underlying) rather than "inflación central."

${ }^{10}$ There are differences in the reported weights across different sources, which may be due to the exact index being used or the date when the weight is reported. Here I use 2010 weights for national CPI according to MEIOECD.
} 
The theoretical argument to target core inflation is relatively simple. Suppose there is set of goods whose prices are fully flexible, while the rest of the prices are sticky. Stabilizing fully sticky price inflation will lead to no distortions in relative prices and full output stabilization. This point was formally shown in Aoki (2001). However, this result is very particular to the model, especially since there are no lags in monetary policy and no transaction frictions. More important, this framework has no second-round effects from shocks in the flexible price sector to sticky price inflation. In this case, targeting core inflation, defined as the one that includes only sticky prices, is optimal.

Indeed, Walsh (2011) argues that the justification for focusing on core inflation relies on the idea that headline and core inflation have the same long-run mean, and non-core inflation has no long-run effects on core inflation. And this is the key assumption that is not warranted by theory and evidence, in particular in emerging market economies where food and energy account for a large fraction of the consumer basket.

In the particular case of energy, the first thing that comes to mind is that it is a key intermediate good, and hence, a rise in oil prices should have an impact on the sticky price sector, so stabilizing headline inflation may prevent excessive second-round effects. In the case of food, three aspects deserve mention. First, many food products, for example grains, are intermediate inputs. Second, although agricultural commodities have deep world markets, there are enough distribution costs to make difficult to think of those goods as having fully flexible prices. Indeed, distribution costs have been one of the main reasons why there is only partial pass-through from exchange rates to domestic prices (Burnstein et al., 2005). Finally, food prices are very important in the consumer basket of many emerging markets, so they may also have significant effects on wage pressures, which also impinge on the overall price level. For all of these reasons, it is not clear that there is a case for ignoring commodity prices in the central bank target.

The original work of Aoki (2001) has been extended in several dimensions to more realistic setups, such as the work by Huang and Zheng (2005) and Bodenstein et al. (2008). The first paper assumes that all goods are produced in two stages, and both are characterized by sticky prices. Intermediate good prices are approximated by the PPI, while final goods by the CPI. Given the feedbacks across sectors, the authors conclude that a reasonable rule should take into account both, CPI and PPI inflation. Bodenstien et al. (2008) in turn analyze the case of energy as an input, and conclude that following a transitory energy shock, policies that react to forecast headline inflation rather than core inflation generate higher output and core inflation volatility. This paper, however, looks at a 20-percent shock in energy prices, which reverts to less than a half of it in the first year, much different to what we have seen in recent episodes.

The assumption that imported prices are subject to pricing-to-market, something more realistic than assuming PPP, has been analyzed by Okano (2007). The paper shows the superiority of targeting CPI rather than PPI, as a proxy to inflation excluding commodities, 
when stabilizing output and inflation. There may be many other reasons that are likely to result in recommending targeting CPI over core CPI, such as the existence of wage stickiness, which may also generate second-round effects difficult to unwind. A pervasive stickiness in countries with a history of high inflation is wage indexation to past CPI. Campolmi (2012) has analyzed the implications of wage stickiness and has shown that this feature allows to rationalize CPI inflation targeting.

More recent research with a particular focus on emerging market economies has shown that food is a significant component of their consumer baskets, much more than in industrialized countries. In a model where there are credit market frictions, namely that a fraction of consumers have no access to credit, Anand and Prassad (2010) show that the central bank should target headline rather than core inflation because of the distributional effects and the spillover from commodity prices to aggregate demand.

In a related work, Catao and Chang (2010), based on the persistence of food inflation and the fact that food inflation is a good predictor of world inflation, show that targeting headline inflation is welfare superior. Their result is based on the fact that the share of food in the consumer basket of emerging markets is much higher than the world average, which may result in a food shock appreciating the currency and deteriorating the terms of trade. A key novelty in this work is that the authors assume that the shock to food prices is persistent.

In discussing optimal monetary policy for commodity exporting countries, Frankel (2010) has proposed targeting the domestic-currency price of exports, as a more moderate alternative to targeting the PPI. This would be similar to core inflation targeting, since monetary policy would not react to the prices of imported commodities, and all the comments I have made on core inflation targeting are still valid under this proposal. Although my focus is on commodity importers, this proposal has the additional problem that for commodity exporters, where the commodity has no relevant domestic consumption, monetary policy would cause excessive exchange-rate fluctuations. A commodity price shock induces a currency appreciation, which under export price targeting would be reinforced by monetary policy tightening, with all the concerns around issues such a Dutch Disease and currency appreciation. As I discuss in the next section, terms of trade shocks that affect aggregate demand require changes in the monetary policy stance under headline inflation targeting, but this response would be less aggressive than the one implied by export price targeting.

Although there may be a case for targeting core inflation it is interesting to note that 26 out of the 27 economies following formal inflation targeting regimes use headline inflation (Hammond, 2012). Moreover, there have been some changes in the index used to define the target, and all of these moves have been drifting away from core inflation targeting to 
headline inflation targeting. ${ }^{11}$ This is the case of the Korean Republic, which moved from targeting core to headline inflation. Only the Central Bank of Thailand targets core inflation, but they are in a transition to targeting headline inflation. In the minutes of the monetary policy meeting of March they state:

In regard to the monetary policy target for 2012, the MPC [Monetary Policy Committee] viewed that the proposal to adopt headline inflation (annual average headline inflation of $3.0 \pm 1.5$ percent per annum) as a monetary policy target remained appropriate. In the long run, this would help enhance the effectiveness of monetary policy communication and strengthen the anchoring of inflation expectations. The Ministry of Finance and related agencies, after discussing the matter in accordance with the cabinet resolution, agreed in principle on the adoption of the new target, but suggested the postponement of the change (...) In order to ensure a smooth transition, the MPC agreed to postpone the adoption of the new monetary policy target to a more appropriate time and retained the current target (quarterly average core inflation of $0.5-3.0$ percent) for this year.

Analytical developments have been evolving to a very eclectic view of what price index to target, while central bank practices have been moving towards targeting headline inflation. Still, core inflation is a key variable to measure underlying inflationary trends. Therefore, it is useful to discuss what other reasons central banks may have to target headline inflation.

The Central Bank of Korea provided a description of the reasons for the change in its target measure in its Monetary Policy Report (2006, September, pp: 71-72):

Core inflation has the merits of less short-term volatilities and greater reactionary effects to the adjustment of the policy rate compared to consumer price inflation, but it also has demerits in that it excludes non-grain agricultural products (weight 4\%) and petroleum products (weight $7.7 \%$ ), which are important for the cost of living, and hence it is thought by the general public to be little related to their daily lives(...) Furthermore, if the Bank were to continue to adopt core inflation while the government employed consumer price inflation as the price index in its plans for the fiscal activities, there would be the likelihood of confusion arising among the general public in judging price levels, which was also thought over. Even though the target index has been changed to headline inflation, core inflation will be monitored continuously as one of the principal reference indicators for the conduct of monetary policy.

Another recent case worth mentioning is the U.S. Since it has no formal inflation target, at least until January 2012, it had a very diffuse definition of the meaning of price stability and what was the appropriate index. The original Taylor rule was done with the GDP deflator, but the measure used in the Federal Open Market Committee (FOMC) discussions was

\footnotetext{
${ }^{11}$ There are some countries that exclude the mortgage components and taxes from the index to target, in order to isolate inflation from monetary and fiscal policy measures. This has been the case during some time in South Africa, Sweden and the U.K. The discussion in this section does not address those issues, but as the indices have been harmonized, most countries have eliminated those corrections, which in the past created sharp swings in headline inflation.
} 
refined over time during the periods of Greenspan and Bernanke. Mehra and Sawhney (2010) show that in the late 1980s it changed to the CPI, then by 2000 moved to PCE (personal consumption expenditure) inflation, and then in 2004 switched to core PCE inflation (excluding food and energy). Since April 2011, when the FOMC began publishing the projections of the members of the Board as well as the governors of regional banks (four times a year), projections have been presented for PCE and PCE core inflation at different horizons, but only PCE at the long run. In January this year the FOMC communicated that (Press release January 25, 2012):

The inflation rate over the longer run is primarily determined by monetary policy, and hence the Committee has the ability to specify a longer-run goal for inflation. The Committee judges that inflation at the rate of 2 percent, as measured by the annual change in the price index for personal consumption expenditures, is most consistent over the longer run with the Federal Reserve's statutory mandate.

Therefore, as it has been moving to an inflation target, the measure has been moving to headline inflation. Indeed, when it had no formal target, it was easier to be ambiguous about the measure, and even emphasize core inflation. But once a target is fully announced, the preferred option is to go for a headline measure. One explanation could be also that once central banks have more credibility it is possible for them to target a measure over which they have less control (IMF, 2011).

Beyond the theoretical assumptions required to support targeting headline inflation, it is worth mentioning the following:

- $\quad$ Easy to communicate. Trying to explain why food and energy are excluded from the cost of living index is no easy task. It is not clear what would be the appropriate price index. Moreover, the public is interested in the stability of prices of the whole consumer basket.

- $\quad$ There is a need for consistency with other price indices used for other policy purposes. As the Bank of Korea highlighted, using a different price to the one used in fiscal plans may lead to inconsistencies, at least from the point of view of communication. This is also the case of many regulated prices that look at headline inflation, such as minimum or public sector wages.

- Using core inflation may induce volatility in expected inflation. From the point of view of wages, the relevant expectation is headline inflation. When core is targeted, the expectations of headline inflation will be more volatile if the target, and hence the anchor, is core inflation. This may end up generating excessive volatility of headline inflation. 
- $\quad$ The original idea for targeting core inflation is that it is less sensitive to shocks and easier to explain: exclude highly volatile products, subject to shocks that have very short duration. The problem is that commodities such as food and oil have shown to have very persistent movements. These fluctuations may have significant secondround effects feeding into core inflation generating larger fluctuations in prices.

- $\quad$ The issue of targeting core inflation usually arises when there are severe CPS. This proposal may look opportunistic, and hence it may reduce the credibility of the central bank regarding its anti-inflationary commitment.

Finally, it is important to note that regardless of whether the central bank targets core or headline inflation, core inflation is a very good measure of the underlying inflationary trends of an economy. Indeed, the central banks of Canada and Norway have been very explicit about the role of core inflation. ${ }^{12}$ Although they target headline inflation they emphasize the role of core inflation in their monetary policy decisions. The measure that excludes food and energy is a good indicator of the inflationary pressures along the business cycle, something that is confirmed by the evidence (Pistelli and Riquelme, 2010). Indeed, the target in Canada is defined in terms of headline inflation, while core inflation is an operational guideline.

\subsection{Should monetary policy react to commodity prices?}

In order to address this question I will present a simple, one-period model that will allow to describe the optimal reaction of monetary policy to CPS and to illustrate the transmission mechanism through which this shock affects the economy.

Consider a central bank that minimizes a quadratic loss function that depends on the deviations of output from full employment $(y-\bar{y})$ and inflation deviations from the target $(\pi-\bar{\pi})$. That is:

$$
\min \left[\lambda(y-\bar{y})^{2}+(\pi-\bar{\pi})^{2}\right]
$$

where $\lambda$ is the relative weight of output deviation vis-à-vis inflation deviations in the loss function. The economy is closed. The inflation process is governed by a Phillips curve, where inflation depends on the inflationary expectations of price and wage setters $\left(\pi^{e}\right)$ and the output gap. The Phillips curve is of the following form:

$$
\pi=\pi^{\mathrm{e}}+\theta(\mathrm{y}-\overline{\mathrm{y}})+\mu
$$

where $\mu$ is a supply shock. In order to assume this is a CPS it is necessary to specify which are the channels through which the CPS affects the Phillips curve. I denote the CPS as $\varepsilon$ and

\footnotetext{
${ }^{12}$ The emphasis these countries place on core inflation had led some classifications to assume they target core inflation, which is not the case.
} 
assume that the central bank observes the shock before making its decision on monetary policy, but the public does not. There are two channels through which $\varepsilon$ affects the Phillips curve. First there is a direct effect on prices. The other is an effect on full employment output. When the commodity is oil, the increase in energy prices corresponds to a decline in productivity, and hence full employment output falls. Therefore, the Phillips curve can be written as:

$$
\pi=\pi^{\mathrm{e}}+\theta(\mathrm{y}-(\overline{\mathrm{y}}-\gamma \varepsilon))+\alpha \varepsilon
$$

which becomes:

$$
\pi=\pi^{\mathrm{e}}+\theta(\mathrm{y}-\overline{\mathrm{y}})+\varepsilon(\alpha+\theta \gamma)
$$

where $\gamma$ corresponds to the effects of commodities on full employment output. For foodstuffs this parameter is zero, while for oil it is positive, and increases with the relative intensity of energy in the production structure of the economy. The parameter $\alpha$ represents the importance of the commodity in the consumer basket, in which case both, oil and food, have a positive effect. However, if the measure of inflation were core, the parameter $\alpha$ would be zero. If the inflation rate is headline inflation we have to take into account the direct effects as well as the indirect, or second-round, effects, while if it is core inflation, we would only include the second-round effects because the direct effects would not be included in the price index. As I reported before, in the case of a food price shock, the value of $\alpha$ is much higher in emerging and developing economies than in industrialized ones.

This is a very simple problem in which the first-order conditions will provide a relation between the output gap and deviations of inflation from the target. Then, using this expression back into the Phillips curve we can have an expression for the rate of inflation as a function of the CPS and expected inflation. This would be the inflation rate the authority would choose to balance the trade-off between inflation and unemployment given inflationary expectations. Inflationary expectations in equilibrium should be equal to the target, but I will assume they are given as it facilitates the discussion on the impact of expected inflation on monetary policy.

However, central banks control inflation indirectly by affecting aggregate demand, which will also be affected by the CPS since for an importing country, the CPS represents a negative shock to the terms of trade, which reduces income and aggregate demand. Denoting by $i$ the interest rate, aggregate demand is assumed to be:

$$
y-\bar{y}=A-\phi\left(i-\pi^{e}\right)-\delta \varepsilon
$$

where $\delta$ stands for the strength of the aggregate demand effect. Of course, for a food exporting country $\delta$ would be negative. Using the expression for inflation and the output gap we can derive the optimal policy rule, which is: 


$$
i=\bar{l}+\frac{\theta}{\phi\left(\theta^{2}+\lambda\right)}\left[\pi^{e}-\bar{\pi}\right]+\varepsilon\left(\frac{\alpha \theta+\gamma \theta^{2}}{\phi\left(\theta^{2}+\lambda\right)}-\frac{\delta}{\phi}\right)
$$

where $\bar{l}$ is the equilibrium nominal interest rate, which is the inflation target plus the equilibrium real interest rate, which in this case is equal to $A / \phi$ (i.e., the real rate when the output gap is zero and inflation is equal to the target).

Equation (5) represents the optimal interest rate in the presence of a CPS. The greater the effect on the supply side, the greater the increase in interest rates when a CPS hits the economy. In contrast, the effect of the CPS on the demand side reduces the strength of the policy response. A pure positive demand shock, or a pure inflationary shock in the Phillips curve requires a stronger reaction of monetary policy, since there are no offsetting effects. In the case of a CPS, the supply-side effect induces monetary tightening, while the demand-side effect limits the extent of the tightening. If the economy were a food exporter, the supply and demand effects would add up, requiring a stronger policy reaction, as $\delta$ would be negative. A way to overcome artificially this effect on some commodity exporting countries is to take advantage of the terms of trade windfall to subsidize the domestic price of the goods that use intensively the commodity. This may generate less inflation transitorily, but at a fiscal cost that may be sizable, especially when the shock is persistent, which is the relevant case I have been discussing.

I have not considered an expectations channel, through which the reaction of expected inflation may depend on whether the target is set in terms of headline or core inflation, and this may have important consequences in the choice of the target.

This analysis has also ignored the dynamic effects of CPS on headline inflation. These are the second-round effects of CPS. A given shock will cause an immediate increase in headline inflation, but it will take some time to affect core inflation. This may arise because commodities are intermediate inputs, or they are relevant in the consumer basket and, hence, on wage determination. Furthermore, the more persistent the CPS, the more likely that the second-round effects will kick off and the greater their inflationary consequences will be. In addition, the larger those second-round effects the more persistent and larger the effects of a CPS on headline inflation.

Another important dynamic implication I have ignored in this discussion is the role the time horizon plays in an inflation targeting regime. Most inflation targeting central banks define a horizon to achieve the target. Sometimes this horizon is explicit, such as two years, which is very prevalent, and sometimes it is more diffusely defined as "medium term."

The horizon is defined based on several considerations. First, monetary policy affects the economy with lags. However these lags are not long enough to justify a choice that goes to the medium run. The other reason is to trade-off the output cost of inflation stabilization. As long as there are output costs, in terms of output deviations from full-employment, the choice od the horizon balances out the costs of the output gap and inflation deviations from the 
target (Svensson, 1997; De Gregorio, 2007). As long as there are temporary shocks to inflation, it would be too costly to maintain inflation at the target at all times. This is what is behind the idea of letting time pass in order to evaluate more accurately the persistence of the shock. But as these shocks do not revert, as the recent experience with food and energy shows, a monetary policy reaction is needed in order not to let inflation become entrenched and more costly to stabilize.

This model has been framed in terms of a closed economy. It adds much more complications to open the economy, but the exchange rate channel may be important in the transmission of the CPS. An economy that is an importer of commodities would, in principle, have a depreciation when commodity prices rise. In this case, the inflationary effects of the rise in world prices may be exacerbated by the depreciation of the currency. In contrast, when the country enjoys a terms of trade gain with the CPS, the ensuing appreciation may ameliorate the effects of the rise in world prices on domestic inflation. These developments should also be taken into account when setting monetary policy. Again, this is not because the central bank targets the exchange rate, but because persistent movements in the exchange rate will have implications on the rate of inflation, and therefore, on the achievement of the inflation target.

\subsection{A caveat: core vs. headline again}

Central banks pay close attention to core inflation, despite targeting headline. Indeed, an increase in headline inflation with core stable leads to a less strong reaction than when the increase is in core inflation. Indeed, this would seem to indicate that central banks are targeting de facto core rather than headline. However, as indicated previously, this different reaction may be due to a different source of inflation. If there is a shock to core inflation, it is likely that the output gap is what is driving the inflationary dynamics. In contrast, a CPS would raise headline but not core inflation, and since it may also have contractionary effects on the demand side, the reaction of monetary policy must be less aggressive.

However, we could establish an equivalence between targeting core and headline inflation if we knew exactly the characteristics of the second-round effects. Let's denote headline inflation by $\pi$, core inflation by $\pi^{\prime}$ and energy and food inflation (commodities, or non-core) by $\pi^{C}$. Headline inflation is a weighted average of its two components: ${ }^{13}$

$$
\pi=\alpha \pi^{\prime}+(1-\alpha) \pi^{C} .
$$

\footnotetext{
${ }^{13}$ I will ignore that weighting is exponential, which does not affect the discussion. In addition, according to (6), if the covariance between core and commodities inflation is positive (most likely), headline inflation will be more volatile than core inflation. In terms of designing an inflation targeting regime, the policy horizon of headline inflation targeting should be longer than that of core inflation targeting (De Gregorio, 2007).
} 
If a CPS $\left(\Delta \pi^{C}\right)$ increases core inflation, as result of second-round effects due to cost or wage push, by a factor of $\sigma$, we have that $\Delta \pi^{\prime}=\sigma \Delta \pi^{C}$. Therefore the relation between a CPS shock and headline inflation is given by: ${ }^{14}$

$$
\Delta \pi=[\alpha \sigma+(1-\alpha)] \Delta \pi^{\mathrm{C}}
$$

The larger the second round effects, measured by $\sigma$, the larger the impact on inflation. If the price shock is permanent, there is a once-and-for-all increase in $\pi^{C}$, which then feeds back to headline inflation, and hence, both core and headline go up transitorily. This is a case in which the relative price of commodities goes up. The increase in commodity inflation, $\Delta \pi^{\mathrm{C}}$, will be transitory, being positive in one period and returning to zero thereafter. If the effects of the transitory shock to inflation, permanent to prices, does take place within the policy horizon and the second-round effects are small, no monetary policy reaction may be needed. Indeed, if there is no propagation, a once-and-for-all increase in commodity prices will lead to a rise in yearly inflation for only 12 months, which is shorter than usual policy horizons. However, in addition to persistent second-round effects due to, say, wage push, we have to consider the possibility that inflationary expectations rise, inducing further propagation of high inflation.

Therefore, what will trigger the central bank's reaction will be the size and persistence of the effects on core inflation. This could be interpreted as targeting core inflation, but as I have argued here, this focus is due to the importance of core inflation as an indicator of underlying inflationary pressures. Therefore, monitoring and reacting more strongly to core inflation is fully consistent with targeting headline inflation. Core inflation is a useful operational guideline, but ignoring developments in headline inflation may impede to take the most adequate monetary policy actions.

Presumably, second-round effects $(\sigma)$ depend on the conduct and credibility of monetary policy. With the expressions described here we cannot tell whether under core or headline inflation $\sigma$ will be smaller. However, as I discussed in the previous section, the increased volatility of headline and expected inflation caused by targeting core inflation may induce greater second-round effects, so it is likely that $\sigma$ would be higher under core inflation targeting. With the framework presented here we can see the trade-off between core and headline inflation targeting. Core inflation targeting will lead to a weaker response of monetary policy (see equation (5) for $\alpha=0$ ), but this could generate more volatility in inflationary expectations, with uncertain effects on output volatility.

\footnotetext{
${ }^{14}$ Since I am ignoring dynamics, one should think this is in a time horizon of, say, one year, otherwise the second-round effect should consider lagged inflation.
} 


\section{Empirical Evidence}

In late 2006 and early 2007 commodity prices skyrocketed like they hadn't since the oil shock of the 1970s, partially reverted during the global crisis, and then started climbing again. A number of countries experienced a significant increase in inflation during this period (figure 4), Chile being one of the most affected. Then, the crisis caused a sharp decline of commodity prices while inflation also declined in most countries. Chile was also one of the countries with the sharpest decline. There are many reasons that can explain the different inflationary performance across countries. In this section I look at cross-country evidence, with a special focus on second-round effects.

\subsection{Previous research and the Chilean experience}

The first shock to commodity prices came with the continuous rise in oil prices since the early 2000s. Indeed, it was quite surprising that after such a significant rise in oil prices, neither inflation nor output around the world were severely affected. The fact that output was spared may be explained by the fact that it was precisely the strong increase in global activity what was pushing up prices. Contrary to previous shocks caused by transitory supply disruptions, this was the result of strong demand with limited supply response (Killian, 2009; Hamilton, 2009). Therefore, understanding the source of the shock is central to interpret the reaction of macroeconomic variables to a rising oil price.

Taking as granted that the strong growth of the global economy previous to the global crisis was behind the increase in oil prices, what was still puzzling was that until 2007 its effects were relatively muted compared to the magnitude of the price hike. ${ }^{15}$ De Gregorio et al. (2007) and Blanchard and Galí (2009) look at the impact of oil price shocks on inflation in a number of economies. Indeed, they find that the pass-through from oil prices to inflation has declined over time, and this is due to in part to the reduced oil dependence of production and consumption, and to better macroeconomic management that by anchoring inflationary expectations reduced the impact of oil prices on medium-term inflationary pressures.

While the oil price kept rising until 2008, food prices also experienced a sharp increase. In many countries inflation kicked off, not at the rates of previous experiences, but the rise in inflation was significant. There was still a low pass-through from oil prices to inflation during the rise in commodity prices because, as reported below, the rise in inflation was mostly due to food products. Indeed, the evidence reported below confirms that food inflation has greater propagation effects than energy inflation.

\footnotetext{
${ }^{15}$ Indeed, the results reported in Killian (2009) show that effects on activity would be limited, but the inflationary effects should be higher. However, the rise in inflation did not take place.
} 
There is some recent research attempting to analyze the sharp rise and fall of inflation, which I will complement with evidence on the most recent surge of commodity prices. Pistelli and Riquelme (2010) examine the relevance of structural and cyclical factors in explaining the difference across countries in the inflation rate of food, energy and core inflation in a sample of 44 countries. They regress the inflation rates on a set of structural and cyclical variables. The structural variables are: (1) domestic restrictions on market prices, (2) domestic price level of food and gasoline, (3) price elasticity of demand, (4) imports of food and energy as shares of expenditure in these items, (5) a dummy for inflation targets, and (6) the exchange rate regime. The cyclical variables are: (1) rate of inflation previous to the boom of commodities, (2) exchange rate variation during the period, and (3) output gap. The results show that structural factors are more relevant in explaining the cross-country differences in food and energy inflation during these episodes, while cyclical factors are more important for core inflation.

During the boom of commodity prices, food inflation was higher in countries with few restrictions to market prices and low food prices. For energy inflation, the price level of gasoline, the dependence on energy imports and the demand elasticity explain the differences across countries. For core inflation, structural factors were not significant, and only the output gap and initial inflation were significant. It is interesting to note that, within this sample, the evolution of the exchange rate did not play a significant role in food, energy and core inflation during the boom of commodity prices and is consistent with the findings that the pass-through from the exchange rate to inflation is relatively limited. This result however does not hold during the fall of commodity prices, but with a pass-through coefficient of the order of 0.1 (i.e., a 10 percent depreciation resulting in a 0.1 percent smaller decline in inflation). The effects on energy and food inflation were somewhat higher. This evidence suggests a potential asymmetry in the effects of exchange rates on inflation.

Using their estimations, Pistelli and Riquelme (2010) attempt to explain the sharp increase in inflation that took place in Chile. According to their estimates, food inflation went relatively higher than in other countries because Chile is a very open economy with non-regulated local markets, so no distortions in the price mechanism, and hence the pass-through should be higher. Chile has a large residual in the estimates of energy inflation, since some idiosyncratic factors also explained a large increase in domestic electricity prices. Finally, regarding core inflation, Chile's increases were close to the median of other countries.

In a recent paper, Gelos and Ustyugova (2012) examine the determinants of propagation in a sample of countries. They find that there is no difference between inflation and non-inflation targeters. However, they find that monetary policy credibility does matter, since countries 
with more independent central banks, and higher governance and regulatory framework scores, managed better the impact of CPS. ${ }^{16}$

The dynamics of the propagation from food and energy prices to core inflation is studied in Pedersen (2011) in a sample of 46 countries. He uses a structural VAR estimation for each country, which can be used to have a sense on how long it takes for the increase in commodity prices to affect core inflation. The evidence shows that the propagation of food price shocks is much larger than that of energy price shocks, which is consistent with the evidence discussed above on the limited effects of oil price changes on inflation. In addition, he shows that propagation is higher in emerging markets than in advanced economies. Part of this must be due to the fact that being food a major component of the consumer basket, its second-round effects due to wage and other cost pressures is higher.

Similar results in terms of relative propagation of energy vis-à-vis food price shocks is reported in Ghezzi et al. (2011), who find that a 10 percent shock in the (WTI) oil price induces a long-term increase of 0.5 percentage point in CPI inflation, while a 10 percent rise in food prices (the food component of the CRB, Commodity Research Bureau, index) increases long-term CPI inflation by 2 percentage points. It is interesting to note that this is not due to a proportional difference in the share of food in the CPI compared to the share of energy. Indeed, in the sample of countries used by these authors the share of energy is 9 percent, while the share of food is 15 percent.

Regarding the time patterns of the shocks, Pedersen (2011) found that average duration is about six quarters, measured as the difference between the first and the last month in which the shock has statistically significant effects on core inflation. It takes some months for the shock to start having effects, and this happens on average during the second quarter. The maximum effect strikes in the fourth quarter.

Now I turn to the response of Chilean inflation to the commodity price shocks. By mid-2007 headline inflation was above the target of 3 percent for annual inflation, but still within the tolerance range that goes from 2 to 4 percent (figure 5). The CPIX1, which the most widely used measure of core inflation in Chile, ${ }^{17}$ was also rising because there was still an important component of processed food in it. However, using the core CPI that excludes all food and energy, which represents about 73 percent of the consumer basket, gives a very different picture. Looking only at current data on this measure of core inflation would have given a tricky reading of the buildup of inflation pressures. Indeed, while headline inflation started

\footnotetext{
${ }^{16}$ Gelos and Ustyugova (2012) also survey other recent empirical evidence.

${ }^{17}$ It excludes perishable goods (fresh fruits and vegetables), gasoline, fresh meat and fish, indexed prices, regulated public utility rates and financial services.
} 
to rise at the beginning of 2007, core inflation kept falling during the first half of 2007. In fact, in July 2007 core inflation was at 1.4 percent, while CPI and CPIX1 inflation stood at 3.8 and 4 percent, respectively. This raises again the issue about the ability of core inflation to anticipate future inflation, and the perils of focusing only on core inflation to determine monetary policy.

The year 2007 ended with headline inflation at 7.2 percent, while core inflation was on the target of 3 percent. During most of 2008 the economy experienced a rapid and unexpected process of propagation from food and energy prices to core inflation, which reverted sharply during the global crisis. Headline inflation declined from levels close to 10 percent by late 2008 to negative inflation in mid-2009. As figure 4 shows, Chile was not only one of the countries where inflation increased the most, but also where the decline was one of the largest.

Chile, as most countries in the world, suffered a recession during 2009. Output fell by 1 percent, somewhat less than the world average, so although the decline in activity played a role in the fall of inflation, it cannot account for the large differences across countries. What comes out from previous research is that the Chilean economy has very low distortions in the price setting mechanism, which can make prices more sensitive to the business cycle. There is no evidence of Chile having a Phillips curve too different from other countries', however it is possible that there may be asymmetries in the reaction of inflation to a boom in activity compared to a recession. Indeed, it is interesting to note an important difference in the rise and fall of inflation. While the rise was initially a rise in headline followed by core, in the fall it was mostly a decline in core inflation (figure 5).

A central element in Chile's inflationary performance was the behavior of food prices. Figure 6 shows food inflation in Chile compared to the average of the sample of 34 countries. While average food inflation in the peak was about 10 percent, in the case of Chile it was twice as much. However in the second price boom (after the crisis) Chile's food inflation has behaved according to the average, and it has not been a source of large inflation deviations from the target. One important reason is that the first episode of food inflation the relative price of food increased significantly, while there was no a parallel fall during the decline in food prices. Figure 7 shows the world relative price of food, using the FAO index of food prices, the relative price of food in Chile and the average for the other countries of the sample. The relative price in Chile increased about 20 percent until late 2008 and then remained relatively stable, to then post a small increase during the most recent boom of commodity prices. In contrast, the relative price in the other countries increased little with respect to the increase of world prices. This has helped to contain inflation, but it cannot be ruled out that at the cost of distortions. Some countries protect enough their agricultural sector so the increase in world prices does not bite locally. In other cases, there are subsidies to food, but, given the persistence of the shock, it is quite difficult they can be sustained, and 
may represent repressed pressures so, as long as world prices do not fall, inflation is just being postponed.

Monetary policy has played an important role in Chile in stabilizing inflation through the implementation of a flexible inflation targeting regime. Of course, the most challenging period from an inflationary point of view was during the first boom of commodity prices. In this period expected inflation one-year ahead was within the tolerance range at the beginning of 2008, while expectations at the policy horizon were consistent with the target of 3 percent. As mentioned before (figure 5), inflation excluding energy and food was close to 3 percent, while headline inflation was at about 7 percent. Monetary policy was tightening since mid2007. A sudden and sharp propagation process took place by the second quarter of 2008 and monetary policy tightened more severely to contain the rising inflationary expectations. This process came to an end after Lehmann's collapse.

The second commodity boom started with the monetary policy rate at its minimum of 0.5 percent. With the economy recovering strongly and commodity prices rising, monetary policy started normalizing. This normalization was done at a faster pace than in previous periods in order to contain the propagation of the inflationary shock and with lessons learned from the first episode of commodity price boom. This resulted in contained inflationary expectations and an evolution of the inflation rate consistent with the inflation target. The most recent data shows that inflationary pressures and propagation from commodities to inflation is still a challenge in the context of a strong economy.

\subsection{On the rise of inflation and the determinants of second-round effects}

As shown in figures 2 and 3, inflation, headline and core, rose in most countries in both episodes of rapid rise of commodity prices in recent years. A next question is to see whether there is a relationship between the rise in inflation in the first episode compared to the second one. For this purpose, in figures 9 and 10 I compare the increase in headline and core inflation across countries. Figure 9 compares the changes in inflation, while figure 10 compares the residuals of a regression of inflation (headline and core) on oil and energy inflation. Thus, figure 10 compares the extra inflation from the average response to commodity prices. An interesting finding in all figures, confirmed later with regressions, is that countries with a greater increase in inflation, headline and core, during the first episode, tend to have a lower increase during the second. This is true for changes in inflation as well as the residuals. This relationship is somewhat stronger for core inflation.

This finding would suggest that countries that had a relative price adjustment during the first episode had less pressure for corrections during the second one, not only through direct effects, but also in second-round effects. This may be due to a number of reasons. Price adjustments occur infrequently and margins adjust over time. The early inflationary shock was able to absorb some of the pressures of the second one. It could also be possible that 
some countries avoided, or mitigated, the first shock via subsidies, administrative measures, moral suasion, or some other form of control. However, the controls may have limited scope, in particular when they involve subsidies or moral suasion, and hence the longer the rise in commodity prices the more likely that sooner or later domestic prices will have to be adjusted.

During the last few years, exchange rates have been subject to significant fluctuations. In particular, commodity exporting countries were benefitted by an increase in the terms of trade, which strengthened their currencies. Alternatively, the strengthening of the currency could have been caused by good economic prospects and capital inflows. Whichever the source of the appreciation, the currency adjustment could have ameliorated the effects of the increase in global prices. Figure 11 plots the depreciation of the nominal exchange rate and the changes in energy and food inflation in both episodes. There is a positive relationship between inflation and depreciation, as expected, but it is relatively weak. Pistelli and Riquelme (2010) found no significant effects of the exchange rate in the run up of commodity prices, only during their fall. In these figures the relationship is weak, but the measure I use is the multilateral exchange rate for each economy, while Pistelli and Riquelme (2010) use the dollar exchange rate. In contrast, Ghezzi et al. (2011) found a significant effect for the depreciation of the exchange rate. This finding shows that exchange rate fluctuations may play an offsetting effect on the inflationary pressures stemming from high commodity prices, however the strength and potential asymmetries of this effect are still unresolved.

Finally, some regressions are presented in order to analyze the impact of energy and food inflation on headline and core inflation in both episodes. The dependent variables are the changes in headline inflation and core inflation. Both measures for the change in inflation are regressed against a number of determinants. The changes in food and energy inflation are lagged one quarter, although using the contemporaneous measure, or lagged two quarters makes no significant differences. I also use the output gap, measured using an HP filter, lagged one quarter. I tried several other variables to measure flexibility and restrictions of domestic prices. I used an index of openness, trade over GDP, and an index of price controls from the Fraser Institute. None of those variables were significant. I also tried measures of exchange rate depreciation, but they were not significant, and this is reasonable given that energy and food inflation is measured in domestic currency. As shown in figure 11, the effects of the exchange rate may already be captured in the levels of energy and food inflation. The only variable that appeared significant in some regressions is the Fraser Institute index of freedom to trade internationally. Towards the end I will also report some regressions that add some variables linked to the behavior of monetary policy.

The results for headline and core inflation are presented in tables 1 and 2, respectively. The effects of food and energy inflation are very similar in both episodes. A 10 percent increase in oil prices raises headline inflation by about 1 to 1.4 percentage points. The effects of food 
inflation are greater. A 10 percent increase in inflation raises inflation, in most regressions, by about 2.5 percentage point. The output gap has a marginally significant effect on headline inflation during this episode, and the index of freedom to trade internationally is mostly insignificant.

An increase in energy and food prices on headline inflation has both direct and second-round effects. To isolate the latter I now turn to the core inflation estimates in table 2. First of all, consistently with previous literature, the estimations show no propagation effects of oil prices into core inflation. Only in some regressions, in particular in episode 1, food inflation appears to have significant second-round effects on core inflation. Moreover, the magnitude of the effect is not that different from the direct effect, since a 10 percent increase in food inflation raises core inflation by about 2 percent in episode 1 . As an approximation, if food and energy represent 25 percent of the consumer basket, the effect of core inflation on headline inflation will be about 1.5 percentage points while the remaining 1 percentage point would be the direct effect.

The output gap is also significant, although marginally, in explaining propagation in episode 1 , since economies that had a wider output gap had a larger increase in core inflation. This is consistent with the evidence for core inflation found by Pistelli and Riquelme (2010). The regressions show, perhaps at first contrary to intuition, that the fewer distortions to international trade an economy had, the lower the increase in inflation during the first episode. One could expect that the easiness to trade should facilitate price adjustment to international shocks, but it also could allow the search for cheaper sources of imports.

Table 3 presents some additional results for episode 1 to explore the role of monetary policy in the rise and propagation of CPS. The regressions include as independent variables the coefficient of variation of inflation in the year previous to the episode, in order to have a proxy for the credibility-performance of monetary policy. Indeed, more stable inflation may be the outcome of a more credible monetary policy, or better inflationary performance due to better external conditions. This is just an imperfect proxy for credibility. In addition, the regressions add an additional variable for the conduct of monetary policy and this is an index of "delay" of the reaction of monetary policy. This index is calculated as the negative value of the residual of a Taylor rule. Therefore, the larger this measure, the higher the interest rate implied by the Taylor rule with respect to the current rate.

The results in table 3 indicate, with marginal significance, that countries with less stable inflation had higher inflation during the first commodity price boom. This result is valid for both core and headline inflation. The coefficient index of monetary policy delay is not significant.

The results for the indirect and indirect impact of energy and food inflation on core and headline inflation are similar to those in tables 1 and 2. Finally, an interesting result is that 
the index of freedom to international trade appears more significant than what was found in previous tables. This result implies that the first commodity price shock had less impact in countries with more open trade accounts. Of course this result depends on the inclusion of the coefficient of variation of inflation; however it suggests that being open to trade does not necessarily imply more exposure to foreign inflation. This issue certainly deserves more research.

Finally, in table 4 I examine whether countries with higher inflation in episode 1 had lower inflation in episode 2 as depicted in figures 9 and 10. As shown in previous tables, results for episode 2 are quite weak regarding most explanatory variables. This table shows that what could have been dominating the dynamics of inflation during the second episode is the magnitude of the rise in inflation during the first episode, in particular core inflation. This evidence suggests that indeed there could have been some repressed inflation during episode 1, which could not been maintained during the second episode. This repressed inflation could have come from two sources. The first is a policy-induced factor. Subsidies or price controls may have limited the rise of inflation in the first episode, but these policies could not be sustained permanently, and during the second episode had to give up. The second channel may have simply to do with the dynamics of pricing across countries. Commodities inflation, in particular food, propagates at different speeds, and in countries were propagation is slower, second-round effects took more time to transmit to the rest of prices, and for this reason the effect is stronger in core rather than headline inflation.

\section{Concluding remarks}

This paper has reviewed some important issues in the area of commodity price inflation and monetary policy. How monetary policy should respond to commodity price shocks has become a first-order concern from the point of view of the achievement of price stability. An optimal response should avoid an overreaction, which could induce large output costs, while preserving stability and mitigating the risk of excessive propagation. The trade-off is intertemporal. Letting inflationary pressures develop may require a stronger reaction of monetary policy in the future as credibility diminishes and inflation rises.

Not responding to CPS has been historically based on the idea that they are transitory and have limited effects on inflation. This may be the case of some specific, low impact, highly volatile goods, such as perishable goods with strong seasonal patterns. However, this is not the case with most commodities whose prices have been rising during the last several years. High commodity prices are part of the landscape for the near future. Commodities, in particular food, represent a significant proportion of the consumer basket in emerging markets, so price stabilization has significant welfare consequences. Their weight in the consumer basket makes them relevant in terms of propagation through wages and prices. 
In this paper I have argued that authorities should not ignore commodity price shocks. As the recent experience has shown, they may transmit to core inflation, creating difficult challenges for monetary policy. Monetary policy should respond to CPS, but this response should be calibrated to the structural characteristics of the economies. In the current juncture, advanced economies pay less attention to commodity price inflation as they are still with significant excess capacity, while the issue of commodity prices is much more relevant in emerging markets, which have recovered strongly from the great recession, and therefore, have greater risks of propagation.

Core inflation, the one that excludes energy and food prices, is still a better indicator than headline inflation for the underlying inflationary pressures in the economy. For this reason the reaction of monetary policy to core vis-à-vis headline inflation should not be the same.

The surge of commodity prices in the second half of the 2000s resulted in important challenges for policymakers and puzzles for academics. The initial response of economies to the oil price surge was relatively muted, but once food prices kicked off, the inflationary outlook become much more complex. Countries that had higher inflation in the first episode appear to have had somewhat less during the second one. In addition countries with fewer restrictions to international trade also seem to have had less inflation. These results are not fully robust, but they indicate that there are a lot of interesting issues to investigate in the microeconomics of the propagation of CPS to inflation.

The regressions reported here show that food and energy have relevant effects in headline inflation, but only the former has significant second-round effects. This result does not imply that one should ignore the inflationary effects of oil prices, since precisely the conduct of monetary policy is one of the determinants of its limited effects on inflation. High credibility of the commitment to the inflation target reduces the required response to maintain price stability in the presence of commodity price shocks, and reduces the costs of achieving price stability. 


\section{References}

Anand, R. and E. Prasad (2010), “Optimal Price Indices for Targeting Inflation under Incomplete markets,” NBER Working paper No. 16290.

Aoki, K. (2001), “Optimal Monetary Policy Responses to Relative-Price Changes,” Journal of Monetary Economics, Vol. 48, No. 1, pp. 55-80.

Batini, N. and E. Tereanu (2010), "Inflation Targeting during Asset and Commodity Price Booms," Oxford Review of Economic Policy, Vol. 26, No. 1, pp. 15-35.

Blanchard, O. and J. Galí (2009), "The Macroeconomic Effects of Oil Shocks: Why Are the 2000s So Different from the 1970s?” in Galí, J. and M. Gertler (eds.) International Dimensions of Monetary Policy, Chicago: Chicago University Press.

Bodenstein, M., C. J. Erceg and L. Guerrieri (2008), “Optimal Monetary Policy with Distinct Core and Headline Inflation,” Journal of Monetary Economics, Vol. 55, Supplement, pp. S18-S33.

Burnstein, A., M. Eichembaum and S. Rebelo (2005), "Large Devaluations and the Real Exchange Rate,” Journal of Political Economy, Vol. 113, No. 4, pp. 742-784.

Campolmi, A. (2012), "Which Inflation to Target? A Small Open Economy with Sticky Wages,” Macroeconomic Dynamics, forthcoming.

Catao, L. and R. Chang (2010), "World Food Prices and Monetary Policy,” NBER Working Paper No. 16563.

De Gregorio, J. (2007), “Defining Inflation Targets, the Policy Horizon and the OutputInflation Tradeoff,” Working paper No. 415, Central Bank of Chile.

De Gregorio, J. and F. Labbé (2011), “Copper, the Real Exchange Rate and Macroeconomic Fluctuations in Chile,” in Arezki, R., T. Gylfason and A. Sy (eds.), Beyond the Curse: Policies to Harness the Power of Natural Resources, Washington D.C.: International Monetary Fund.

De Gregorio, J., O. Landerretche and C. Neilson (2007), "Another Pass-Through Bites the Dust? Oil Prices and Inflation,” Economia, Vol. 7, No. 2, pp. 155-196.

Frankel, J. (2010), “A Comparison of Monetary Policy Anchor Options, Including Product Price Targeting, for Commodity-Exporters in Latin America," NBER Working Paper No. 16362. 
Galí, J. (2008), Monetary Policy, Inflation, and the Business Cycle: An Introduction to the New Keynesian Framework, Princeton, NJ: Princeton University Press.

Galí, J. and M. Gertler (2007), "Macroeconomic Modeling for Monetary Policy Evaluation,” Journal of Economic Perspectives, Vol. 21, No. 4, pp. 25-45.

Gelos, G. and Y. Ustyugova (2012), "Inflation Response to Commodity Price Shocks - How and Why do Countries Differ,” mimeo, International Monetary Fund.

Ghezzi, P., L. Ricci and J. Zuñiga (2011), “Easy Money Is Not for All EM: Rising Focus on Commodity Prices and EM Inflation,” Barclays Capital, Emerging market Research.

Hamilton, J. (2009), “Causes and Consequences of the Oil Shock of 2007-08,” Brookings Papers on Economic Activity, Spring, pp. 215-259.

Hammond, G. (2012), State of the Art of Inflation targeting, Handbook No. 29, Centre for Central Banking Studies, Bank of England.

Huang, K. and L. Zheng (2005), “Inflation Targeting: What Inflation Rate to Target,” Journal of Monetary Economics, Vol. 52, No. 8, pp. 1435-1462.

IMF (2011), World Economic Outlook, September, chapter 3, Washington DC: International Monetary Fund.

Killian, L. (2009), “Not All Oil Price Shocks are Alike: Disentangling Demand and Supply Shocks in the Crude Oil Market,” American Economic Review, Vol. 99, No. 3, pp. 1053-1069.

Lenza, M. and L. Reichlin (2011), "Should the ECB Use Core Inflation as a Signal for Medium-Term Inflation?” VoxEU.org.

Medina, J.P. and C. Soto (2005), “Oil Shocks and Monetary Policy in an estimated DGSE Model for a Small Open Economy,” Working Paper No. 353 Central Bank of Chile.

Mehra, Y. and B. Sawhney (2010), "Inflation Measure, Taylor Rules and the GreenspanBernanke Years,” Economic Quarterly, Federal Research Bank of Richmond, Vol. 96, No. 2, pp. 123-151.

Okano, E. (2007), “The Choice of the Inflation Rate as a Target in an Economy with Pricingto-Market,” Japan and the World Economy, Vol. 19, No. 1, pp. 48-67.

Pedersen, M. (2011), “Propagation of Shocks to Food and Energy Prices: An International Comparison,” mimeo, Central Bank of Chile. 
Pistelli, A. and V. Riquelme (2010), “Auge y Caída de Precios de Commodities y su Impacto sobre Precios Domésticos: Comparacion Internacional,” Working Paper No. 567, Central Bank of Chile.

Svensson, L. (1997), “Inflation Forecast Targeting: Implementing and Monitoring Inflation Targets,” European Economic Review, Vol. 41, No. 6, pp. 1111-1146.

Svensson, L. (1999), “Inflation Targeting as a Monetary Policy Rule,” Journal of Monetary Economics, Vol. 43, No. 3, pp. 691-720.

Walsh, J. (2011), “Reconsidering the Role of Food Prices in Inflation,” IMF Working Paper No. $11 / 71$.

Woodford, M. (2003), Interest and Prices: Foundations of a Theory of Monetary Policy, Princeton: Princeton University Press.

Woodford, M. (2007), “The Case for Forecast Targeting as a Monetary Policy Strategy,” Journal of Economic Perspectives, Vol. 21, No. 4, pp. 3-24. 
Table 1: Regression Results for Headline Inflation

\begin{tabular}{|c|c|c|c|c|c|c|}
\hline & \multicolumn{3}{|c|}{ Episode 1} & \multicolumn{3}{|c|}{ Episode 2} \\
\hline & (1) & $(2)$ & (3) & (4) & (5) & (6) \\
\hline Energy inflation (-1) & $\begin{array}{r}0.13^{* * *} \\
(0.03)\end{array}$ & $\begin{array}{r}0.13^{* * *} \\
(0.03)\end{array}$ & $\begin{array}{r}0.14 * * * \\
(0.03)\end{array}$ & $\begin{array}{r}0.10 * * * \\
(0.02)\end{array}$ & $\begin{array}{r}0.11^{* * *} \\
(0.02)\end{array}$ & $\begin{array}{r}0.11^{* * *} \\
(0.02)\end{array}$ \\
\hline Food inflation (-1) & $\begin{array}{r}0.26 * * * \\
(0.07)\end{array}$ & $\begin{array}{r}0.27^{* * *} \\
(0.08)\end{array}$ & $\begin{array}{r}0.25^{* * *} \\
(0.07)\end{array}$ & $\begin{array}{r}0.28^{* * *} \\
(0.07)\end{array}$ & $\begin{array}{c}0.17^{* *} \\
(0.07)\end{array}$ & $\begin{array}{r}0.25^{* * *} \\
(0.07)\end{array}$ \\
\hline Output gap (-1) & & $\begin{array}{c}0.16^{*} \\
(0.08)\end{array}$ & $\begin{array}{c}0.21^{* *} \\
(0.09)\end{array}$ & & $\begin{array}{c}0.13 \\
(0.13)\end{array}$ & $\begin{array}{c}0.21 * \\
(0.11)\end{array}$ \\
\hline Freedom to int'l trade & & $\begin{array}{l}-0.38 \\
(0.26)\end{array}$ & & & $\begin{array}{c}1.21^{*} \\
(0.68)\end{array}$ & \\
\hline Constant & $\begin{array}{l}-0.02 \\
(0.44)\end{array}$ & $\begin{array}{r}2.53 \\
(1.90)\end{array}$ & $\begin{array}{l}-0.43 \\
(0.46)\end{array}$ & $\begin{array}{c}0.21 \\
(0.58)\end{array}$ & $\begin{array}{l}-9.03 * \\
(4.66)\end{array}$ & $\begin{array}{l}-0.43 \\
(0.63)\end{array}$ \\
\hline No. of obs. & 35 & 34 & 35 & 35 & 34 & 35 \\
\hline Degrees of freedom & 32 & 29 & 31 & 32 & 29 & 31 \\
\hline Adjusted R2 & 0.62 & 0.66 & 0.65 & 0.48 & 0.53 & 0.49 \\
\hline $\mathrm{R} 2$ & 0.64 & 0.70 & 0.68 & 0.51 & 0.59 & 0.54 \\
\hline
\end{tabular}

Standard deviations in parentheses.

${ }^{*}$ : significant at $10 \%$, **: significant at $5 \%$, ***: significant at $1 \%$. 
Table 2: Regression Results for Core Inflation

\begin{tabular}{|l|ccc|ccc|}
\hline & \multicolumn{3}{|c|}{ Episode 1 } & \multicolumn{3}{c|}{ Episode 2 } \\
& $(1)$ & $(2)$ & $(3)$ & $(4)$ & $(5)$ & $(6)$ \\
\hline \multirow{4}{*}{ Energy inflation (-1) } & & & & & & \\
& 0.04 & 0.03 & 0.06 & 0.02 & 0.03 & 0.03 \\
Food inflation (-1) & $(0.06)$ & $(0.03)$ & $(0.04)$ & $(0.02)$ & $(0.03)$ & $(0.02)$ \\
& $0.16^{*}$ & $0.21^{* *}$ & 0.12 & $0.17^{*}$ & 0.08 & 0.15 \\
Output gap (-1) & $(0.09)$ & $(0.10)$ & $(0.07)$ & $(0.08)$ & $(0.08)$ & $(0.09)$ \\
& & $0.31^{*}$ & $0.44^{* * *}$ & & 0.08 & 0.16 \\
Freedom to int'I trade & & $(0.16)$ & $(0.15)$ & & $(0.17)$ & $(0.14)$ \\
& & $-0.91^{* *}$ & & & 1.00 & \\
Constant & & $(0.37)$ & & & $(0.86)$ & \\
& 0.08 & $6.21^{* *}$ & -0.41 & -0.73 & -8.38 & -1.20 \\
No. of obs. & $(0.60)$ & $(2.49)$ & $(0.51)$ & $(0.70)$ & $(5.87)$ & $(0.78)$ \\
Degrees of freedom & & & & & & \\
Adjusted R2 & 35 & 34 & 35 & 35 & 34 & 35 \\
R2 & 32 & 29 & 31 & 32 & 29 & 31 \\
\hline
\end{tabular}

Standard deviations in parentheses.

$*$ : significant at $10 \%,{ }^{* *}$ : significant at $5 \%,{ }^{* * *}$ : significant at $1 \%$. 
Table 3: Additional Regression Results for Episode 1

\begin{tabular}{|l|cc|cc|}
\hline & \multicolumn{2}{|c|}{ Episode 1 - Headline } & \multicolumn{2}{c|}{ Episode 1 - Core } \\
& $(1)$ & $(2)$ & $(3)$ & $(6)$ \\
\hline \multirow{4}{*}{ Energy inflation (-1) } & & & & \\
& $0.12^{* * *}$ & $0.13^{* * *}$ & 0.01 & 0.00 \\
& $(0.02)$ & $(0.03)$ & $(0.04)$ & $(0.04)$ \\
& $0.26^{* * *}$ & $0.26^{* * *}$ & $0.20^{*}$ & $0.20^{*}$ \\
Output gap (-1) & $(0.08)$ & $(0.08)$ & $(0.10)$ & $(0.10)$ \\
& 0.00 & -0.03 & $0.26^{*}$ & $0.26^{*}$ \\
Inflation - Coef. of variation & $(0.07)$ & $(0.07)$ & $(0.14)$ & $(0.14)$ \\
& $0.38^{* *}$ & $0.35^{* *}$ & $0.46^{* *}$ & $0.46^{* *}$ \\
Index of delay in monetary policy & $(0.17)$ & $(0.20)$ & $(0.18)$ & $(0.18)$ \\
Freedom to int'I trade & & 0.29 & & $-0.02^{* *}$ \\
Constant & & $(0.25)$ & & $(0.32)$ \\
& $-0.67^{* * *}$ & $-0.55^{* * *}$ & $-1.14^{* * *}$ & $-1.15^{* * *}$ \\
No. of obs. & $(0.30)$ & $(0.38)$ & $(0.36)$ & $(0.38)$ \\
Degrees of freedom & $5,46^{* *}$ & $4.62^{*}$ & 0.21 & -0.43 \\
Adjusted R2 & $(2.12)$ & $(2.67)$ & $(0.58)$ & $(0.63)$ \\
R2 & & & & \\
\hline
\end{tabular}

Standard deviations in parentheses.

*: significant at $10 \%$, **: significant at 5\%, ***: significant at $1 \%$. 
Table 4: Additional Regression Results for Episode 2

\begin{tabular}{|l|cc|cc|}
\hline & \multicolumn{2}{|c|}{ Episode 2 - Headline } & \multicolumn{2}{c|}{ Episode 2 -Core } \\
& $(1)$ & $(2)$ & $(3)$ & $(4)$ \\
\hline \multirow{4}{*}{ Energy inflation (-1) } & & & & \\
& $0.11^{* * *}$ & $0.09^{* * *}$ & -0.02 & -0.03 \\
& $(0.03)$ & $(0.03)$ & $(0.03)$ & $(0.03)$ \\
Output gap (-1) & $0.16^{* *}$ & $0.16^{* *}$ & $0.09^{*}$ & 0.09 \\
& $(0.07)$ & $(0.06)$ & $(0.05)$ & $(0.06)$ \\
Inflation - Coef. of Variation & 0.22 & 0.13 & 0.17 & 0.07 \\
& $(0.15)$ & $(0.17)$ & $(0.18)$ & $(0.18)$ \\
Index of delay in monetary policy & -0.07 & -0.05 & 0.02 & 0.05 \\
Freedom to int'I trade & $(0.13)$ & $(0.12)$ & $(0.14)$ & $(0.13)$ \\
Inflation amplitude - Episode 1 & & 0.69 & & 0.78 \\
Constant & & $(0.50)$ & & $(0.51)$ \\
& 1.20 & $1.25^{*}$ & 0.44 & 0.49 \\
& $(0.73)$ & $(0.64)$ & $(0.81)$ & $(0.73)$ \\
No. of obs. & $-0.32^{*}$ & -0.26 & $-0.82^{* * *}$ & $-0.81^{* * *}$ \\
Degrees of freedom & $(0.17)$ & $(0.17)$ & $(0.26)$ & $(0.28)$ \\
Adjusted R2 & $-8.31^{*}$ & $-7.74 *$ & -2.63 & -1.79 \\
R2 & $(4.76)$ & $(4.29)$ & $(5.04)$ & $(4.81)$ \\
& & & & \\
& 34 & 34 & 34 & 34 \\
& 27 & 26 & 27 & 26 \\
& 0.56 & 0.59 & 0.33 & 0.39 \\
& 0.64 & 0.68 & 0.46 & 0.52 \\
\hline
\end{tabular}

Note: "Inflation amplitude - Episode 1" denotes the change in inflation during episode 1. For regressions (1) and (2), the variable "Inflation amplitude - Episode 1" corresponds to the amplitude of headline inflation during the first episode. For regressions (3) and (4), this variable corresponds to the amplitude of core inflation during the first episode. 
Figure 1: Commodity Prices

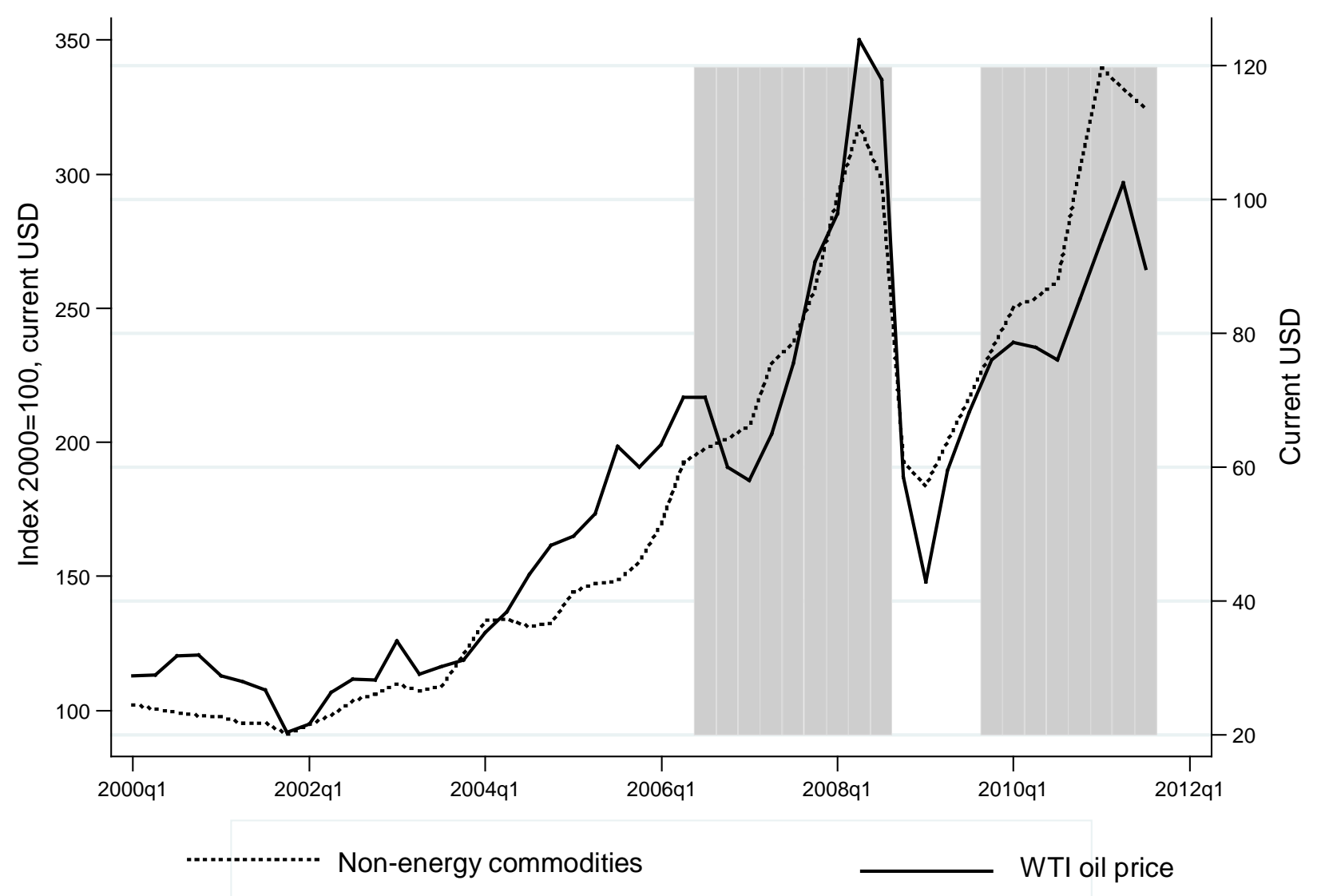

Source: World Bank, GEM Data. The shaded areas correspond to the two-year booms. 
Figure 2: Change in inflation: 2006Q3-2008Q3

Energy inflation
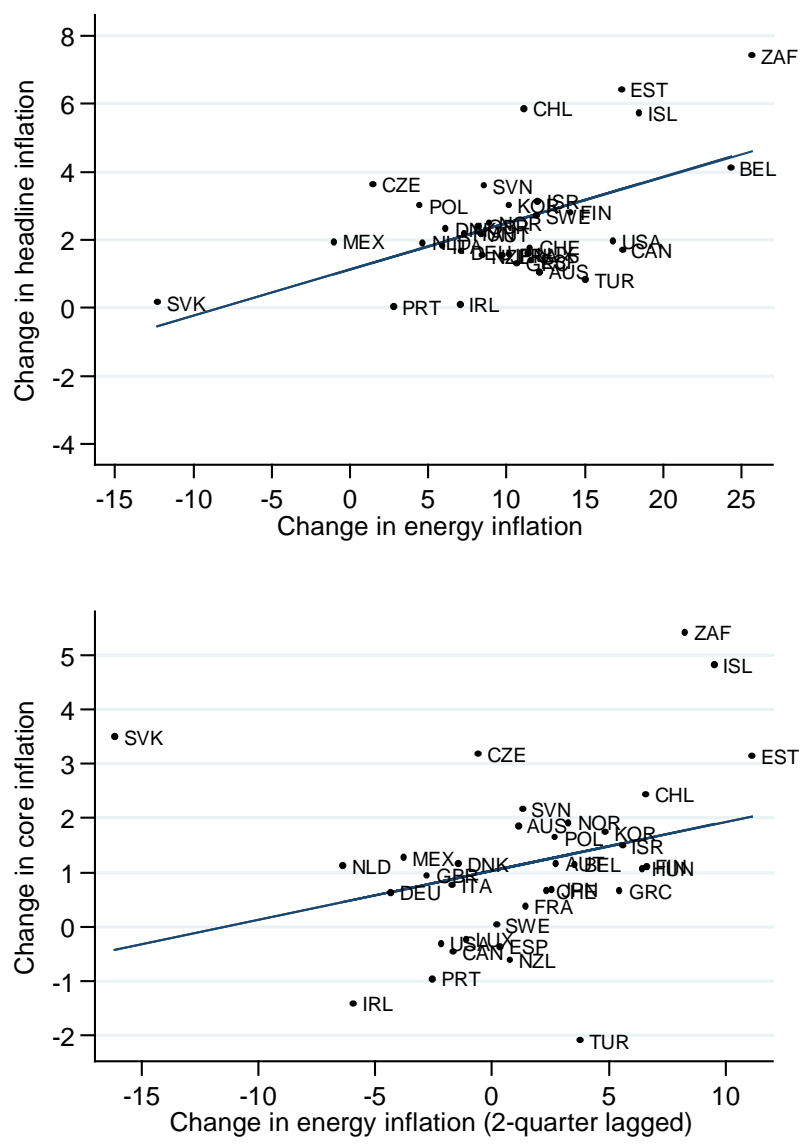

Food inflation
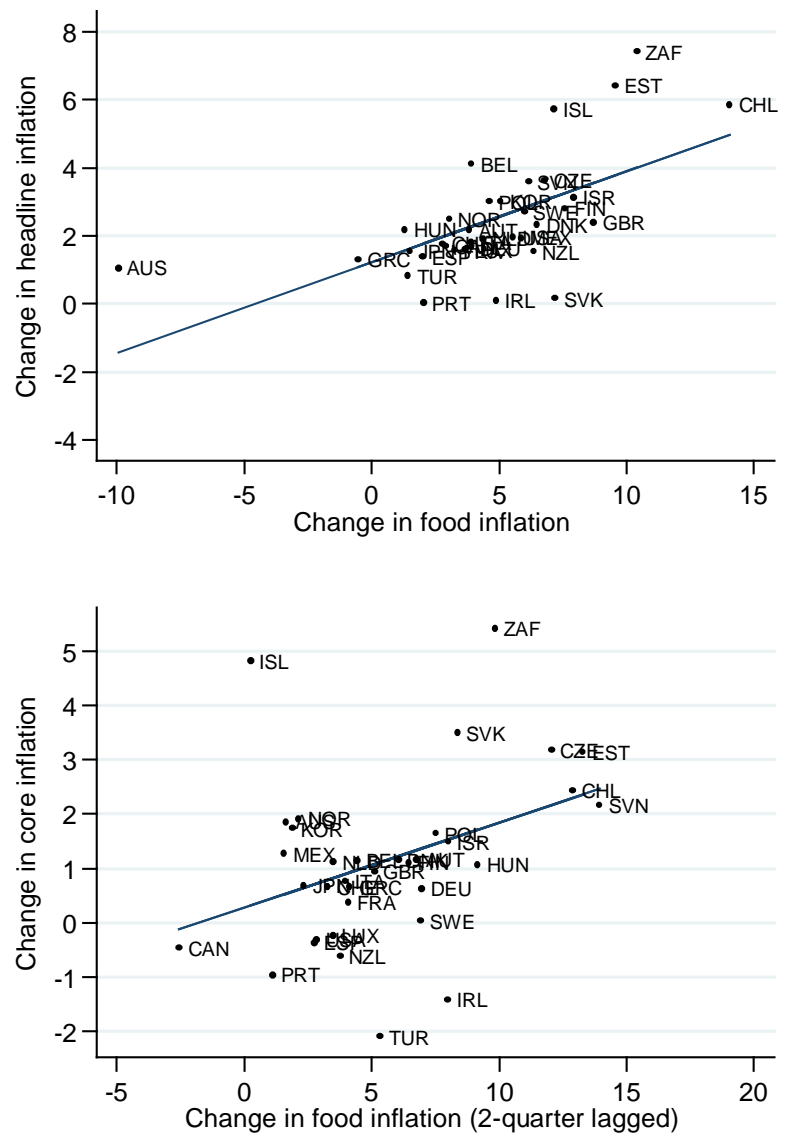

Note: "Delta inflation” denotes the change in inflation (“top"-“bottom”) during episode. Source: MEI-OECD data. 
Figure 3: Change in inflation: 2009Q3-2011Q3

Energy inflation
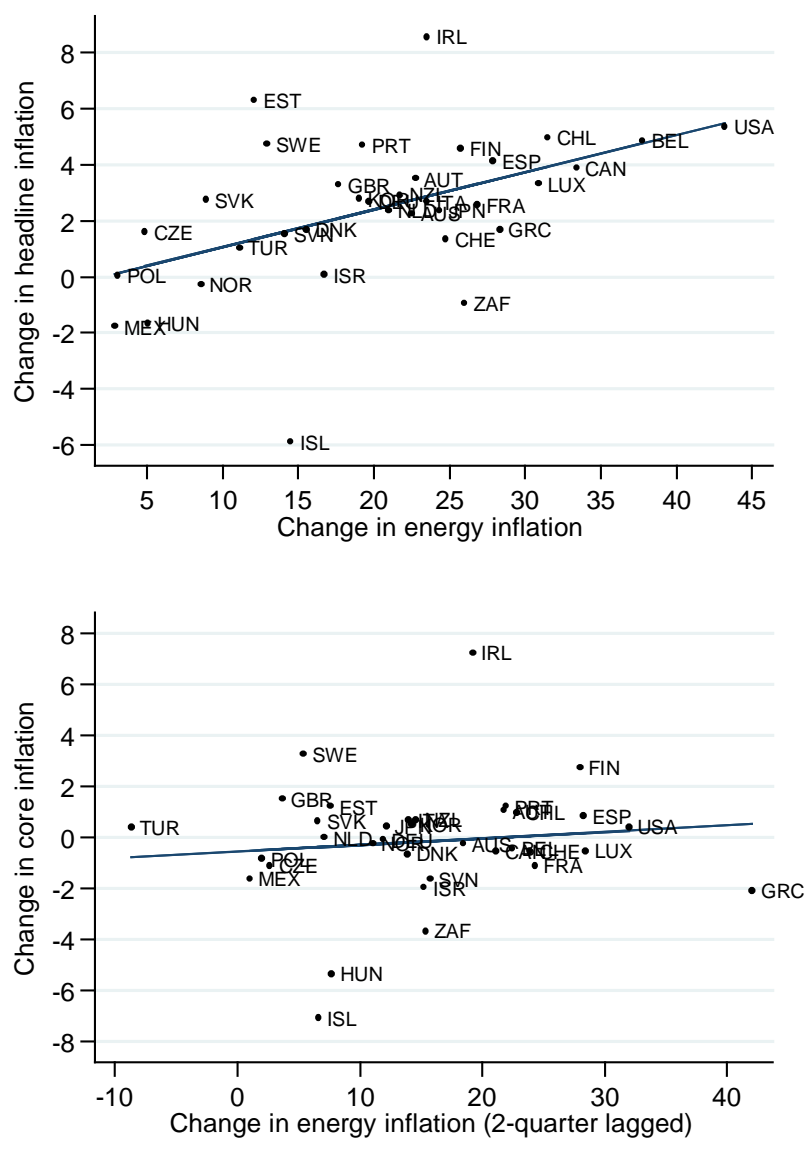

Food inflation
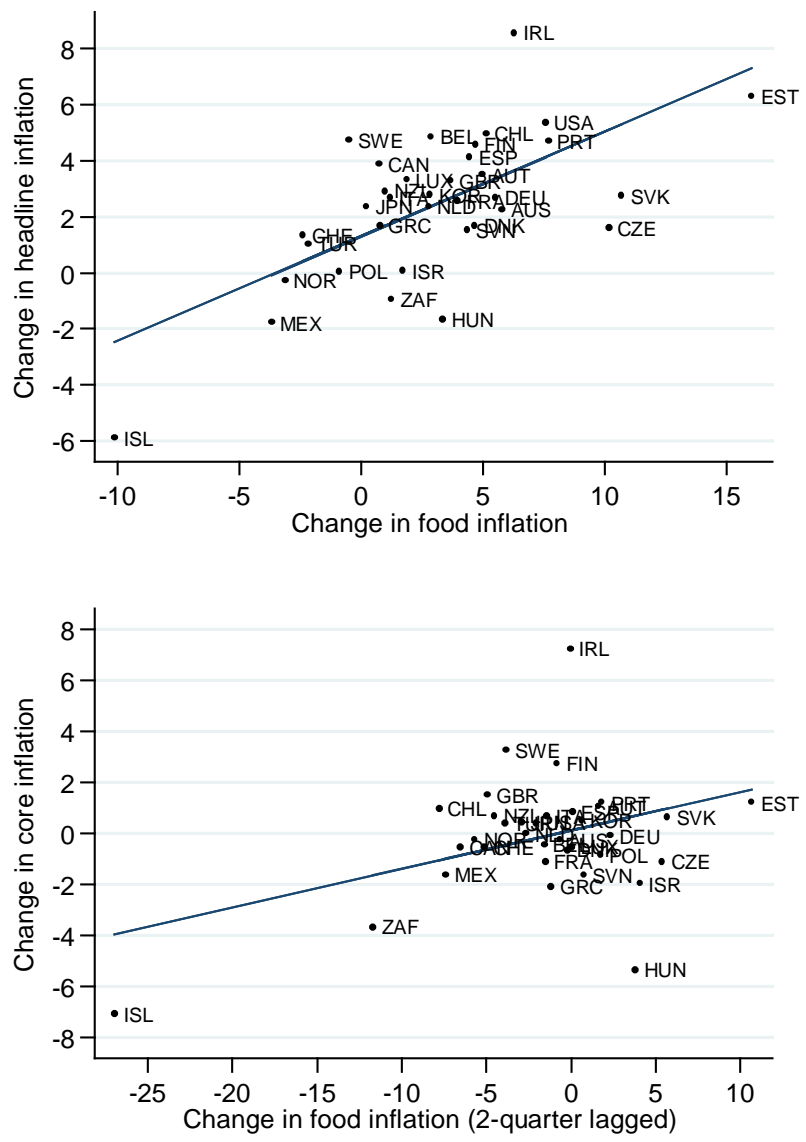

Note: "Delta inflation” denotes the change in inflation (“top”-“bottom”) during episode. Source: MEI-OECD data. 
Figure 4: Accumulated CPI Changes (percent)

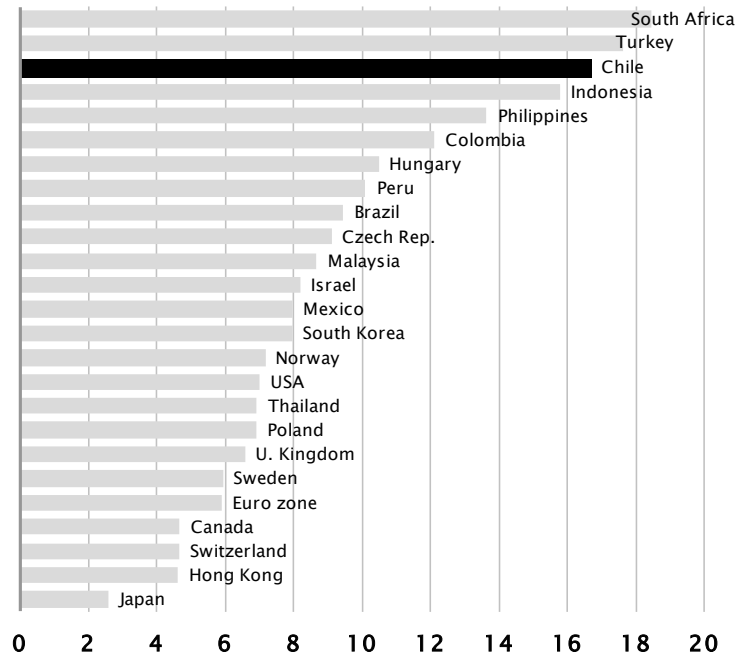

January 2007 - October 2008

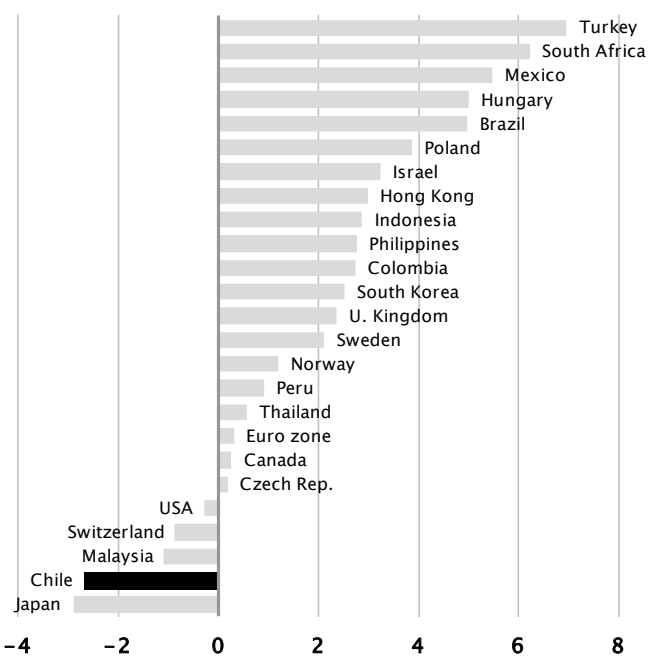

October 2008 - December 2009

Sources: Statistics bureaus at each country and Bloomberg.

Figure 5: Inflation in Chile (y-o-y, percent)

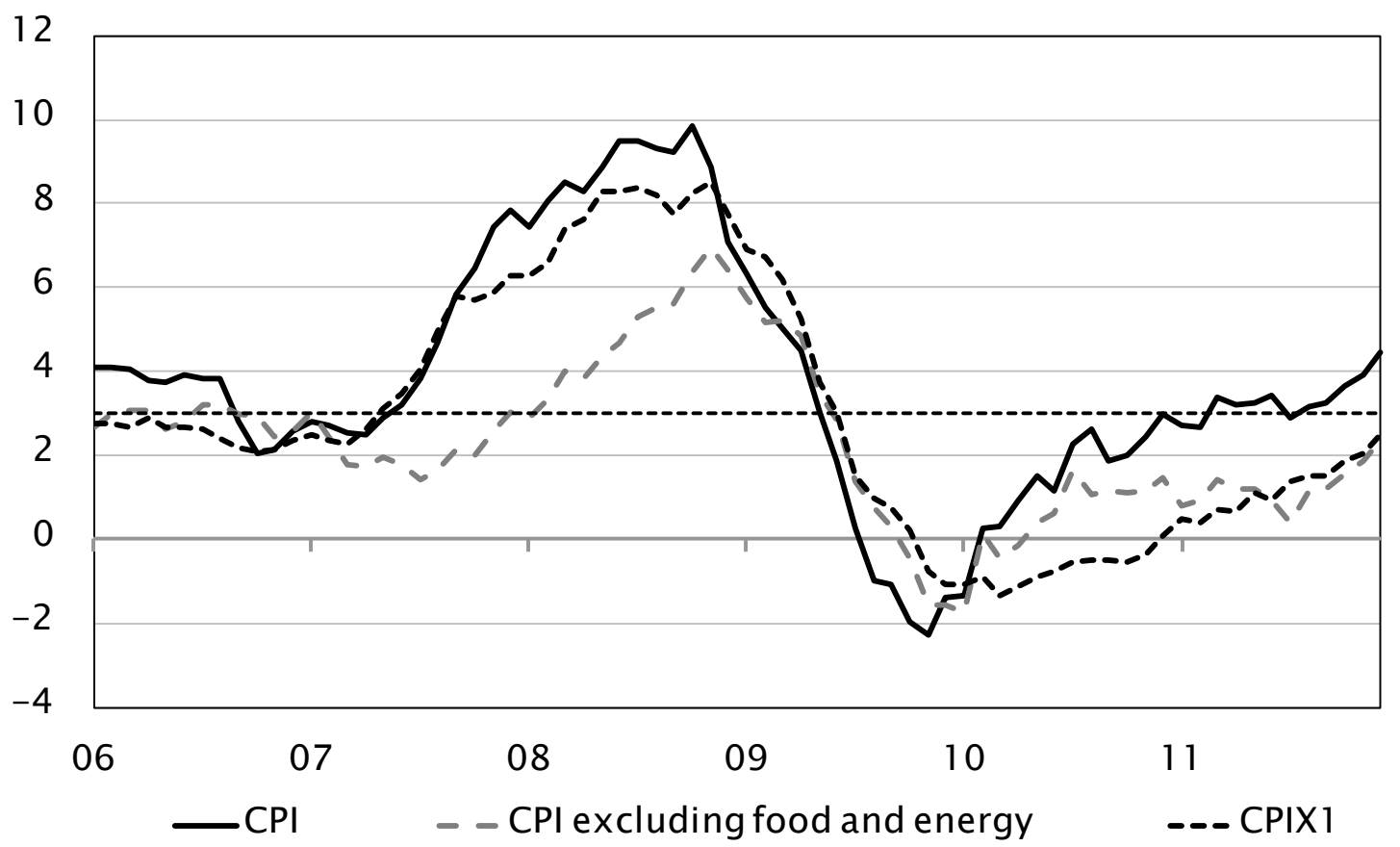

Source: Central Bank of Chile. 
Figure 6: Food inflation

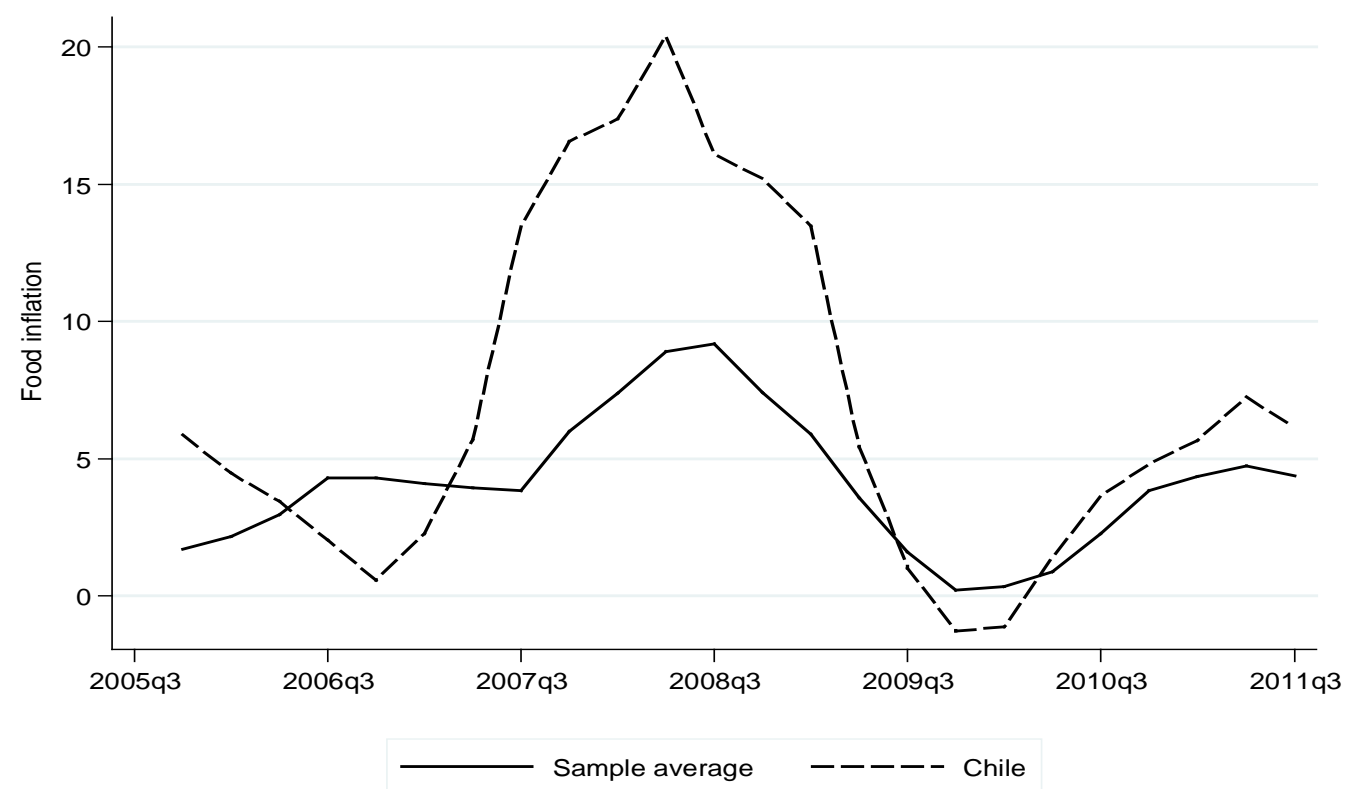

Source: MEI-OECD data.

Note: World food inflation is calculated as the simple mean of 4-quarter food inflation across 34 countries (excluding Chile).

Figure 7: Real food price index

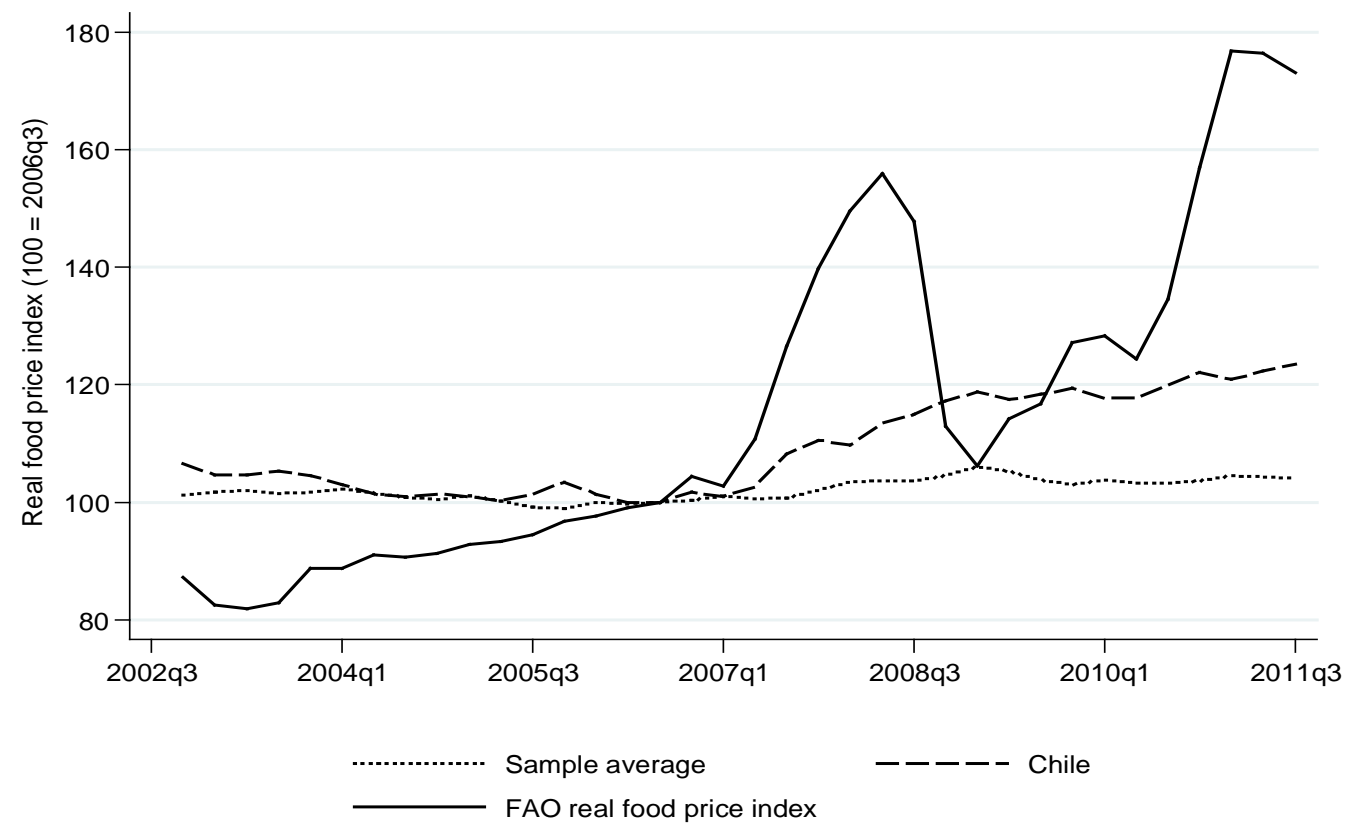

Note: For Chile, the real food price index corresponds to the CPI of food divided by headline CPI. The "Sample average" is the average of this ratio across 34 countries (excluding Chile). All indices are normalized such as $2006 q 3=100$. The FAO- real food price index corresponds to the nominal food price index deflated by the World Bank Manufactures Unit Value Index (MUV). Source: The real food price index is calculated with MEI-OECD data, which is available at: http://stats.oecd.org/Index.aspx?DatasetCode=MEI_PRICES. The FAO real price index is available at: http://www.fao.org/worldfoodsituation/wfs-home/foodpricesindex/en/. 
Figure 8: Chile, inflationary expectations and monetary policy

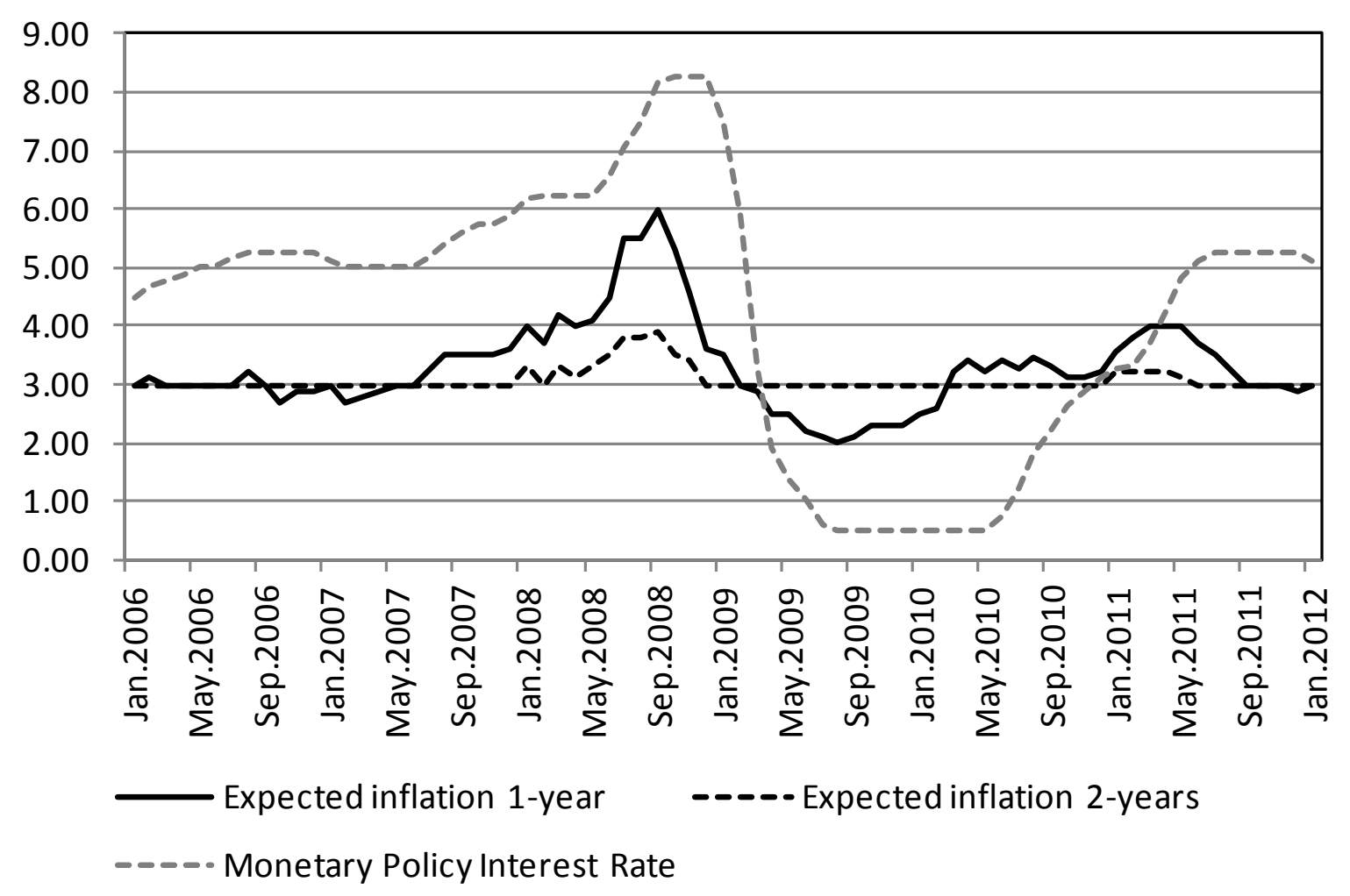

Source: Central Bank of Chile. 
Figure 9: Change in inflation during episodes

Headline inflation

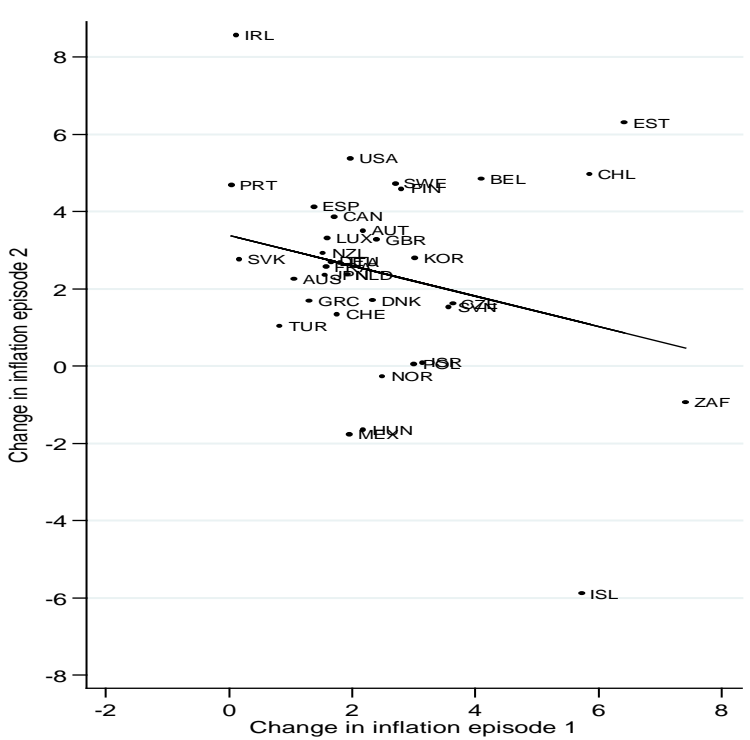

Core inflation

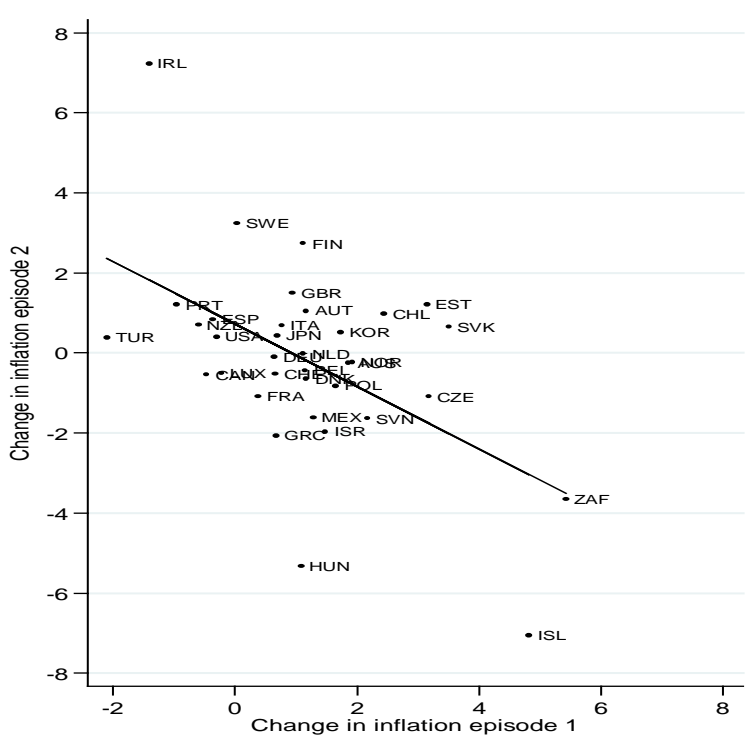

Source: MEI-OECD data.

Figure 10: Residuals

Headline inflation

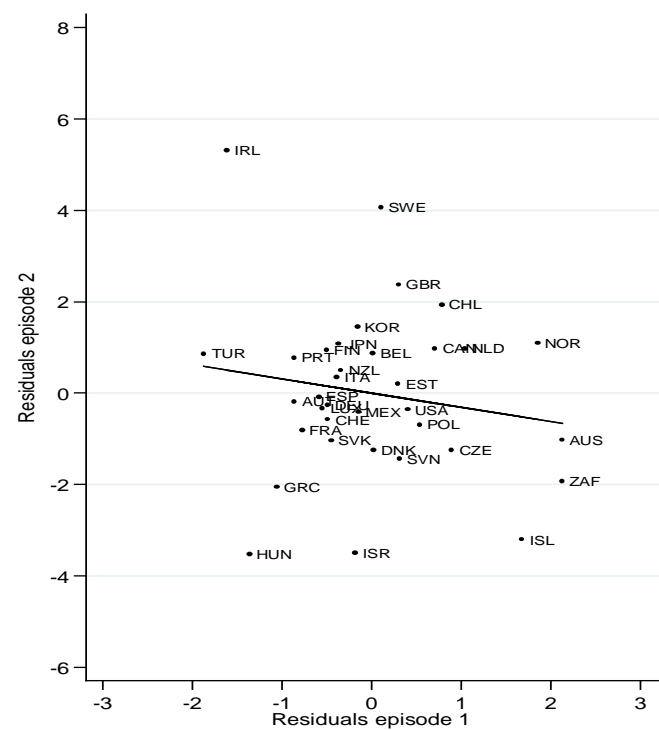

Core inflation

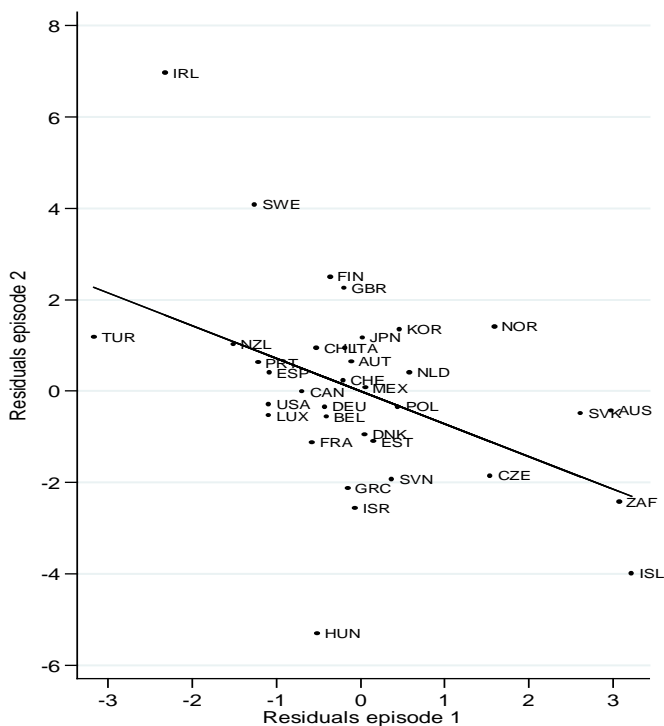

Note: Residuals result from a linear regression where the independent variable corresponds to the change in headline and core inflation, and the dependent variables are lags of changes in food and energy inflation. Source: MEI-OECD data. 
Figure 11: Exchange rate and energy \& food inflation

Episode 1: 2006Q3-2008Q3
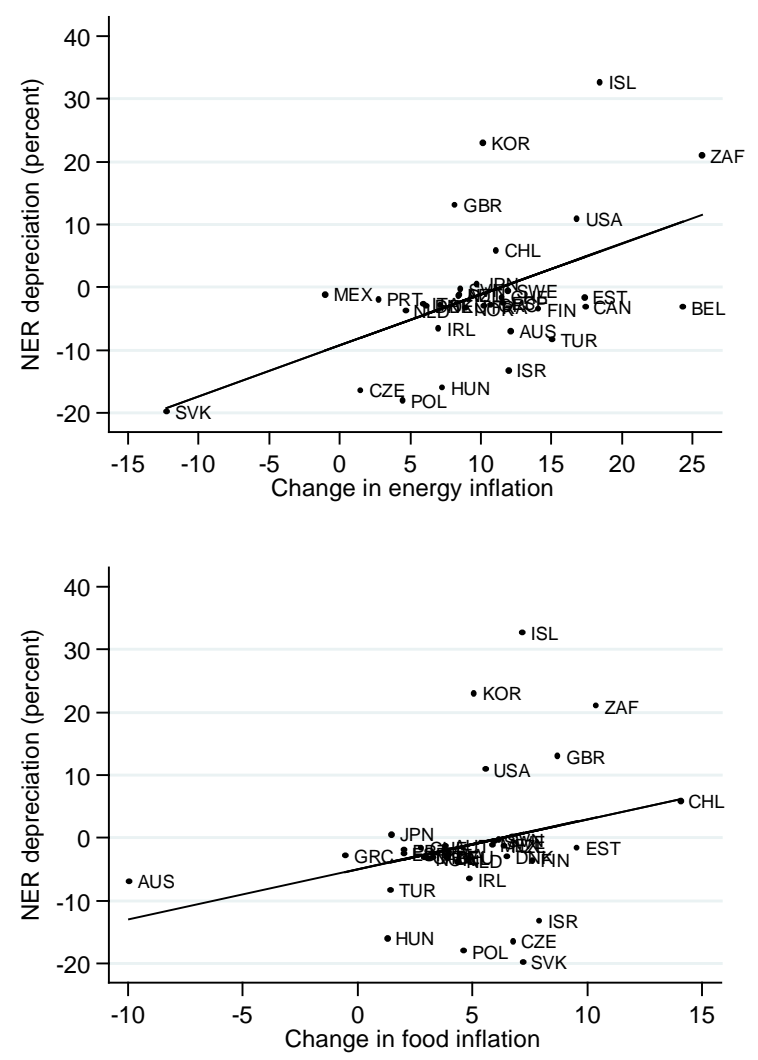

Episode 2: 2009Q3-2011Q3
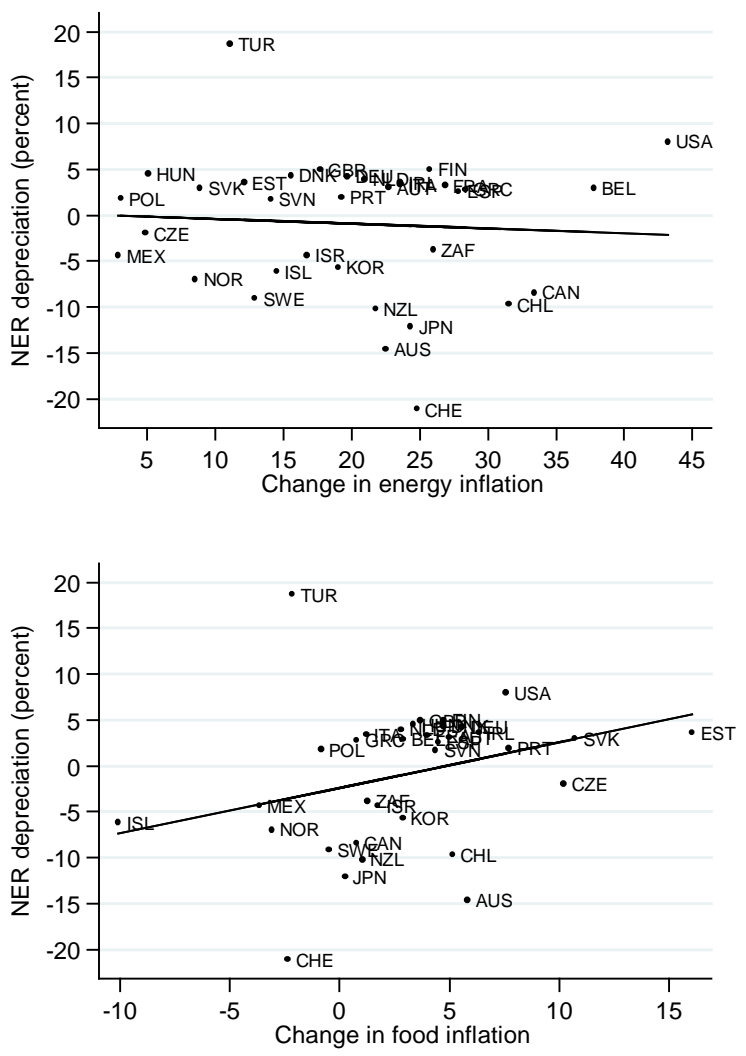

Note: The nominal exchange rate (NER) has been modified such as a decrease denotes an appreciation. Each line corresponds to a linear adjustment.

Source: MEI-OECD data for inflation and the BIS-Nominal Broad Index for the nominal exchange rate (NER). Available at http://www.bis.org/statistics/eer/index.htm. The NER corresponds to a multilateral exchange rate which is calculated as the geometric weighted average. 